\title{
Nano-Bainitic Steels: Acceleration of Transformation by High Aluminum Addition and Its Effect on Their Mechanical Properties
}

\author{
Mohamad Akram ${ }^{1}\left(\mathbb{D}\right.$, Mohamed Soliman $^{1,2, *}$ and Heinz Palkowski ${ }^{1}{ }^{\mathbb{D}}$ \\ 1 Institute of Metallurgy, Clausthal University of Technology, 38678 Clausthal-Zellerfeld, Germany; \\ mohamad.abdelaziz@tu-clausthal.de (M.A.); heinz.palkowski@tu-clausthal.de (H.P.) \\ 2 Faculty of Engineering, Galala University, Galala City 43511, Egypt \\ * Correspondence: mohamed.soliman@tu-clausthal.de
}

Citation: Akram, M.; Soliman, M.; Palkowski, H. Nano-Bainitic Steels: Acceleration of Transformation by High Aluminum Addition and Its Effect on Their Mechanical Properties. Metals 2021, 11, 1210. https:// doi.org/10.3390/met11081210

Academic Editor: C. Issac Garcia

Received: 2 July 2021

Accepted: 26 July 2021

Published: 29 July 2021

Publisher's Note: MDPI stays neutral with regard to jurisdictional claims in published maps and institutional affiliations.

Copyright: (c) 2021 by the authors. Licensee MDPI, Basel, Switzerland. This article is an open access article distributed under the terms and conditions of the Creative Commons Attribution (CC BY) license (https:// creativecommons.org/licenses/by/ $4.0 /)$.

\begin{abstract}
Additions of 3 and $5 \mathrm{wt} . \% \mathrm{Al}$ have been investigated as a low-cost method for transformation acceleration in nano-bainitic steels. For both $\mathrm{Al}$ contents, two groups of steels with C-content in the range $\sim 0.7$ to $\sim 0.95 \mathrm{wt} . \%$ were studied. Thermodynamic and physical simulations were used in alloy and heat treatment design. Characterization was performed via dilatometry, scanning and transmission electron microscopy, Synchrotron X-ray diffraction, and tensile and impact testing. Fast bainitic-transformation time-intervals ranging from 750-4600 s were recorded and tensile strengths up to $2000 \mathrm{MPa}$ at a ductility of $\sim 10$ elongation percent were attainable for the $3 \mathrm{wt}$ \% Al group at an austempering temperature of $265^{\circ} \mathrm{C}$. Higher $\mathrm{Al}$ additions were found to perform better than their lower $\mathrm{Al}$ counterparts as the austempering temperature is dropped. However, Al lowered the austenite stability, increased the martensite start temperature, austenitization temperatures and, consequently, the prior austenite grain size, as well as limiting the austempering temperatures to higher ones. Additionally, the lowered austenite stability coupled with higher additions of hardenability elements (here carbon) to maintain the martensite start at around $300^{\circ} \mathrm{C}$, causing the $5 \mathrm{wt} . \% \mathrm{Al}$ group to have a large amount of low stability retained austenite (and consequently brittle martensite) in their microstructure, leading to a low elongation of around $5 \%$.
\end{abstract}

Keywords: nano bainite; carbide free bainite; advanced high strength steel (AHSS); retained austenite; mechanical properties; Al content

\section{Introduction}

In order to optimize the properties of nano-bainite $(\mathrm{nB})$ steel, it is essential to understand the nature of its transformation and consider the different factors contributing to and resulting from it. The nucleation of bainite starts at the $\gamma$ grain boundaries as well as at crystal defect sites. It further proceeds via an autocatalytic mechanism utilizing the newly generated $\alpha-\gamma$ interfaces as new nucleation sites [1-5]. The growth mechanism of bainite is a displacive one that is plastically accommodated by deformation in the surrounding austenite. Newly formed bainitic ferrite platelets are initially supersaturated with $C[6,7]$. Depending on the transformation temperature and alloying elements present, this entrapped $C$ will either diffuse into the surrounding austenite grains, or precipitate into carbide [6]. When carbide-free, low temperature $\mathrm{nB}$ is desired, cementite suppressing elements (such as Si and Al) are added and, consequently, austenite is enriched with C [8].

Tailoring the mechanical properties of $\mathrm{nB}$ means controlling the size and fraction of the phases obtained. The strength of the $\mathrm{nB}$ derives from the fine, nano-sized platelet structure produced [8]. The contribution of the retained $-\gamma\left(\gamma_{\mathrm{r}}\right)$ to the mechanical properties of the steel produced is, however, not as straightforward. $\gamma_{\mathrm{r}}$ exists in the following two forms inside the microstructure: large $\gamma_{\mathrm{r}}$ islands and film $\gamma$ growing between the bainitic-ferrite platelets $[9,10]$. Upon loading, $\gamma_{\mathrm{r}}$ islands are susceptible to a strain-induced transformation 
into martensite (TRIP), owing to its lower stability, and lower C content at the center of $\gamma_{\mathrm{r}}$-grains [11]. While this phenomenon improves ductility at low rates of deformation, it is detrimental to the impact properties of the steel produced. The drop in impact properties is attributed to the constant formation of a brittle martensitic phase at the advancing crack tip via the TRIP effect [10]. This transformation can, however, be suppressed through the stabilization of $\gamma_{\mathrm{r}}$ by the presence of a surrounding hard phase, or by refining the grain size. Consequently, the film $\gamma$ produced during the bainitic transformation at low temperatures would be more stable and less prone to the TRIP effect at low stresses [4,9]. In this respect, Asako et al. reported that the martensite/austenite (M/A) islands, resulting from the low stability of large austenite grains discussed earlier, negatively influence the fracture toughness of the aforementioned steels [12]. Micro-cracks are initiated at the M/A grains and then propagate through the boundaries between $\mathrm{M} / \mathrm{A}$ and ferrite leading to brittle fracture. On the other hand, micro-cracks initiated in film austenite do not catastrophically propagate, and only cause void formation leading to ductile fracture. Yang et al. further report that the presence of ductile $\gamma_{\mathrm{r}}$ films between bainitic ferrite platelets serve to blunt the tip of an advancing crack, hence improving the overall toughness of the steel [13]. The major obstacle hindering the industrial utilization of $\mathrm{nB}$ is that the fine structures required necessitate low transformation temperatures, and, consequently, long transformation times. Continuous research is directed toward reducing bainitic transformation times via alloying additions and process modifications [4,8,13-17].

The transformation kinetics are highly dependent on the driving force for bainitic ferrite formation, which is the difference in free energy between ferrite and austenite. Increasing the change in free energy when austenite transforms to ferrite at a constant temperature would accelerate the transformation kinetics. Alloying additions are employed to alter the relative stabilities of austenite and ferrite, hence changing the driving force. Additions of up to $2 \% \mathrm{Co}$ and $\mathrm{Al}$ are reported in the literature to increase the change in free energy associated with bainitic ferrite formation, thus accelerating the transformation [18-20]. Caballero and Bhadeshia used additions of $1.54 \mathrm{wt} . \% \mathrm{Co}$, and 1.6 wt.\% Co and 0.99 wt. \% Al to accelerate a conventional high carbon $\mathrm{nB}$ alloy. They report a much larger acceleration effect with the addition of both $\mathrm{Co}$ and $\mathrm{Al}$ than when only adding Co. Another positive advantage of adding $\mathrm{Co}$ and $\mathrm{Al}$ would be that they are $\alpha$-stabilizers; hence, more bainite is expected to be formed. Consequently, the amount of blocky austenite is reduced and its stability is increased; therefore, the resulting mechanical properties are improved [20]. On the other hand, the literature sources covering high Al steels report difficulties and surface defects during continuous casting. This is caused by the $\mathrm{Al}$ reacting with the mold flux powders used. However, these casting difficulties can be avoided through an appropriate selection of mold flux material [21,22].

Cobalt is an expensive element that is-from an economical point of view-best avoided. Attempts have been made to completely replace the accelerating effects of Co with additions of $\mathrm{Al}$ and/or reduction in $\mathrm{Mn}$, which retards the transformation by increasing the austenite stability [14,23]. Yoozbashi et al. developed a Co-free, high C $(0.65-0.85 \mathrm{wt} . \% \mathrm{C})$ $\mathrm{nB}$ alloy with $0.7-1 \mathrm{wt} . \% \mathrm{Al}$ additions, the transformation times for these alloys at 300 , 250, and $200{ }^{\circ} \mathrm{C}$ were 6,16 , and $72 \mathrm{~h}$, respectively, with ultimate tensile strengths (UTS) of up to $2000 \mathrm{MPa}$ [14]. Another Co-free nB alloy was developed by Yang et al. with $0.83 \mathrm{wt} . \% \mathrm{C}$ and $1.44 \mathrm{wt} . \% \mathrm{Al}$. The transformation time was reported to be 4,12 , and $24 \mathrm{~h}$ at 260,240 , and $220^{\circ} \mathrm{C}$, respectively, with an ultimate tensile strength reaching up to $2375 \mathrm{MPa}$ [13]. Tian et al. report that a $0.5 \mathrm{wt} . \% \mathrm{Al}$ promotes the bainitic transformation during both isothermal treatments and continuous cooling in an $0.22 \mathrm{wt} . \% \mathrm{C}, 1.8 \mathrm{wt} . \%$ $\mathrm{Si}, 2 \mathrm{wt} . \% \mathrm{Mn}$, and $0.23 \mathrm{wt} . \% \mathrm{Cr}$ alloy [24]. Other recent attempts at accelerating the transformation kinetics rely on process modifications such as ausforming [2,4,11], the prior generation of a small martensite fraction $[25,26]$, and intercritical annealing followed by austempering [1,9].

While the effect of $\mathrm{Al}$ on the bainitic transformation has been well published, the available literature sources do not cover $\mathrm{Al}$ additions in excess of $2 \mathrm{wt} . \%$. The objective of 
this research is to fill the gap, studying the effect of adding 3 and $5 \mathrm{wt} \% \mathrm{Al}$ on the bainite transformation of a high $\mathrm{C}$ steel alloy, aiming to develop a low-cost alternative for fast transforming $\mathrm{nB}$ steels.

\section{Materials and Methods}

The alloys studied were cast in a vacuum furnace into blocks with dimensions $31 \times 31 \times 150 \mathrm{~mm}^{3}$, homogenized at $1100{ }^{\circ} \mathrm{C}$ for $48 \mathrm{~h}$ in an Ar-atmosphere, followed by slow cooling in the oven. The homogenized blocks were hot rolled at $1100{ }^{\circ} \mathrm{C}$ to an 8-millimeter thickness sample using a 12" 2-high rolling machine, followed by oven cooling. The compositions of the rolled steels are given in Table 1.

Table 1. Chemical composition of the studied alloys in wt.\%.

\begin{tabular}{cccccccc}
\hline Alloy & C & Mn & Si & Al & Mo & B & Fe \\
\hline 31 & 0.766 & 0.98 & 0.27 & 3.08 & 0.45 & - & Balance \\
32 & 0.838 & 0.98 & 0.28 & 3.09 & 0.46 & - & Balance \\
33 & 0.954 & 0.99 & 0.28 & 3.02 & 0.45 & - & Balance \\
51 & 0.672 & 0.98 & 0.26 & 5.03 & 0.44 & 0.0008 & Balance \\
52 & 0.717 & 0.99 & 0.27 & 4.97 & 0.44 & 0.0012 & Balance \\
53 & 0.935 & 0.98 & 0.26 & 4.75 & 0.47 & 0.0013 & Balance \\
\hline
\end{tabular}

New alloying concepts were applied in designing the alloys studied. High Al contents of $3 \mathrm{wt}$ \% (3-group) and $5 \mathrm{wt. \%}$ (5-group) were added as the main means of transformation acceleration. Mn content was maintained at around $1 \mathrm{wt} \%$ to counteract the drop in hardenability associated with the high amounts of Al added, while at the same time retarding the transformation kinetics [27]. Si was reduced to approximately $0.3 \mathrm{wt} \%$ as it becomes redundant in the presence of high amounts of $\mathrm{Al}$, which serves the same role of cementite inhibition. The high (5 wt.\%) Al was micro-alloyed with B to improve its hardenability, i.e., to prevent its high temperature decomposition into ferrite and pearlite while cooling, as a result of the hardenability-loss due to the high Al content. Mo was added to improve hardenability and counteract temper embrittlement.

TCFE9 database of ThermoCalc software (Version 2020.1.60405-124, Thermo-Calc Software, Stockholm, Sweden) was used to simulate the phase diagrams of the studied alloys for estimating their austenization temperatures. Dilatometry testing was performed using a Bähr Dil 805A dilatometer (TA instruments, New Castle, DE, USA) on $5 \mathrm{~mm}^{\varnothing} \times 10 \mathrm{~mm}$ cylindrical specimens machined from the rolled plates, the dilatometric experiments were performed under vacuum and He gas was used for cooling to enable the high quenching rates required during the heat treatments. A schematic representation of the thermal cycles employed to generate the $\mathrm{nB}$ microstructures is provided in Figure 1. Further details of the austenitization as well as the austempering temperatures is provided in the Sections 3 and 4.

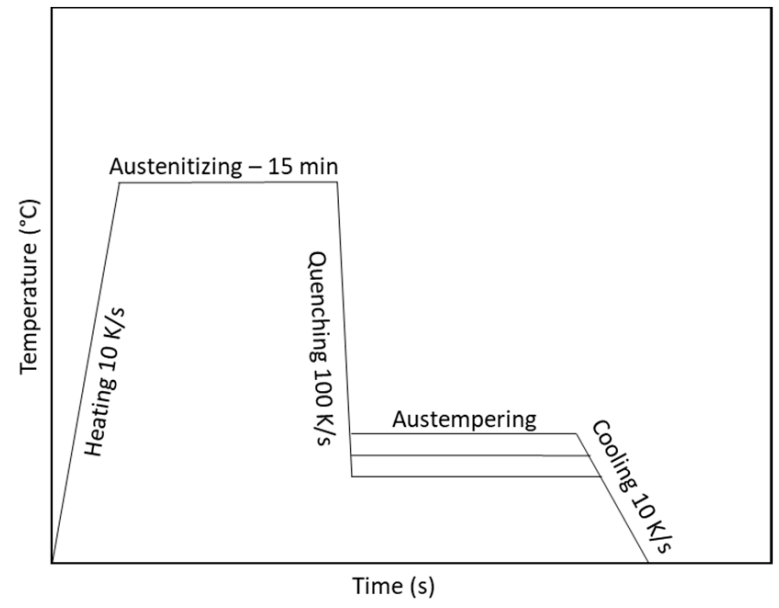

Figure 1. Thermal cycles used to produce the nB microstructures. 
Dilatometry specimens were then tempered at $200{ }^{\circ} \mathrm{C}$ for $2 \mathrm{~h}$ to reveal any possible martensite during microscopy, according to the method described in [28]. Specimens were ground and polished using standard techniques followed by deep Nital etching, and gold sputtering for investigation under SEM. The SEM micrographs obtained were used to measure the bainite thickness with the assistance of ImageJ image analysis software (Version 1.53, NIH, Bethesda, MD, USA), a total of 100 measurements were taken per condition, 10 images per specimen, and 10 measurements per image. The true lamellar thickness, " $\mathrm{t}$ ", was obtained via measuring the mean linear intercept, " $\mathrm{Lt}$ ", normal to the length of the lamellae, as viewed under the SEM. However, Lt does not represent the actual thickness of the bainitic lamellae, and a stereological correction is required provided by the relationship, $t=2 \mathrm{Lt} / \pi$. Selected samples for transmission electron microscopy (TEM) were prepared using the focus ion beam (FIB) method utilizing FEI STRATA FIB 205 device (FEI, Hilsboro, OR, USA). The TEM investigations were performed using Tecnai F20 TEM (FEI, Hilsboro, OR, USA) under a $200 \mathrm{kV}$. The martensitic specimens quenched directly after austenitization were prepared according to the procedure provided in [29] to reveal the prior austenite grain boundaries. Average grain size measurements were performed by applying the intercept technique on the entire surface of $5 \mathrm{~mm}^{\varnothing} \times 10 \mathrm{~mm}$ dilatometric specimens. A Zeiss Evo 15 SEM (Carl Zeiss AG, Jena, Germany) equipped with an Oxford Ultim Max EDX analyzer (Oxford Instruments, Abingdon, United Kingdom) was used for EDX mapping of element segregation, as well as the detection of precipitates.

Tensile testing was performed on heat-treated ASTM E8 sub-size round specimens with a gauge length of $12.5 \mathrm{~mm}$ and $2.5 \mathrm{~mm}^{\varnothing}$ using a Zwick/Roell universal testing machine (Zwick Roell Geoup, Ulm, Germany) with a $250 \mathrm{kN}$ load cell. The machine is equipped with a video extensometer for accurate strain measurements. Charpy impact testing was performed on heat-treated ASTM E23 notched sub-size specimens with a length of $50 \mathrm{~mm}$ and a cross section of $5 \mathrm{~mm} \times 5 \mathrm{~mm}$. The sub-sized specimens with the aforementioned dimensions were chosen to enable their controlled heat treatment in the dilatometer using the same thermal cycles presented in Figure 1. Synchrotron X-ray diffraction (XRD) analysis was performed at the Deutsches Elektronen-Synchrotron (DESY) facility (DESY, Hamburg, Germany) on transformed dilatometry specimens, $\gamma_{\mathrm{r}}$ percentages were calculated from the integrated intensities of the (111), (200), (220), and (311) austenite diffraction peaks and the (110), (200), (211), (220) ferrite diffraction peaks according to the method described by Cullity [30]. The austenite carbon content was determined using the following Equation (1), which is based on the Dyson and Holmes equation [31]:

$$
\mathrm{C}_{\gamma}=\left(\mathrm{a}_{\gamma}-0.3578-0.000095 \mathrm{w}_{\mathrm{Mn}}-0.00056 \mathrm{w}_{\mathrm{Al}}-0.00031 \mathrm{w}_{\mathrm{Mo}}\right) / 0.0033
$$

where $C_{\gamma}$ is the retained austenite carbon content, $a_{\gamma}$ is the retained austenite lattice parameter in $\mathrm{nm}$, and $\mathrm{w}_{\mathrm{X}}$ is the weight percent of the relevant substitutional element in the austenite. Due to the nature of the bainitic transformation being under conditions of para-equilibrium, the substitutional alloying elements are not expected to partition during the transformation. Hence, the composition of substitutional elements in the $\gamma_{\mathrm{r}}$ is expected to be the same as the nominal composition of the alloy for the purposes of calculating the $\mathrm{C}_{\gamma}$ [32]. Additionally, while Equation (1) does not take the effect of Si into consideration, work by Dyson and Holmes indicates that the effect of Si on $\mathrm{a}_{\gamma}$ is minor compared to the other elements [31]. Moreover, there is precedent in the current literature for the use of Equation (1) with nB alloys with Si content significantly higher than that used in this present work [32,33].

\section{Results}

\subsection{Dilatometry}

Thermodynamic simulation using ThermoCalc software indicates that the full austenitization temperatures are 884,850 , and $820^{\circ} \mathrm{C}$ for the 31,32 , and 33 alloys, respectively. An austenitization temperature of $950{ }^{\circ} \mathrm{C}$ was chosen for the three-group. 
On the other hand, discrepancies were detected between the thermodynamically simulated and dilatometric experimental results for the five-group alloys. Figure 2a shows the phase diagram of the five-group alloy system. As can be seen from the figure, the theoretical austenitization temperatures for the five-group alloys should lie between 888 and $1000{ }^{\circ} \mathrm{C}$. Nevertheless, the microstructural investigations on the quenched samples after austenitization showed that the full austenitization is not achieved up to $1280^{\circ} \mathrm{C}$ for alloy 51; for alloys 52 and 53, full austenitization is only achievable at 1200 and $1250^{\circ} \mathrm{C}$, respectively. Optical microscopy images of alloy 53 after austenitization for $15 \mathrm{~min}$ at $1250{ }^{\circ} \mathrm{C}$ and quenching to room temperature (Figure $2 \mathrm{~b}$ ) clearly display the presence of ferrite grains. Full austenitization temperatures were used for alloys 52 and 53, while alloy 51 was heated to a temperature of $1150{ }^{\circ} \mathrm{C}$, which corresponds to a volume fraction of $0.1 \delta$-ferrite in the microstructure, with an average grain diameter of $27 \mu \mathrm{m}$.
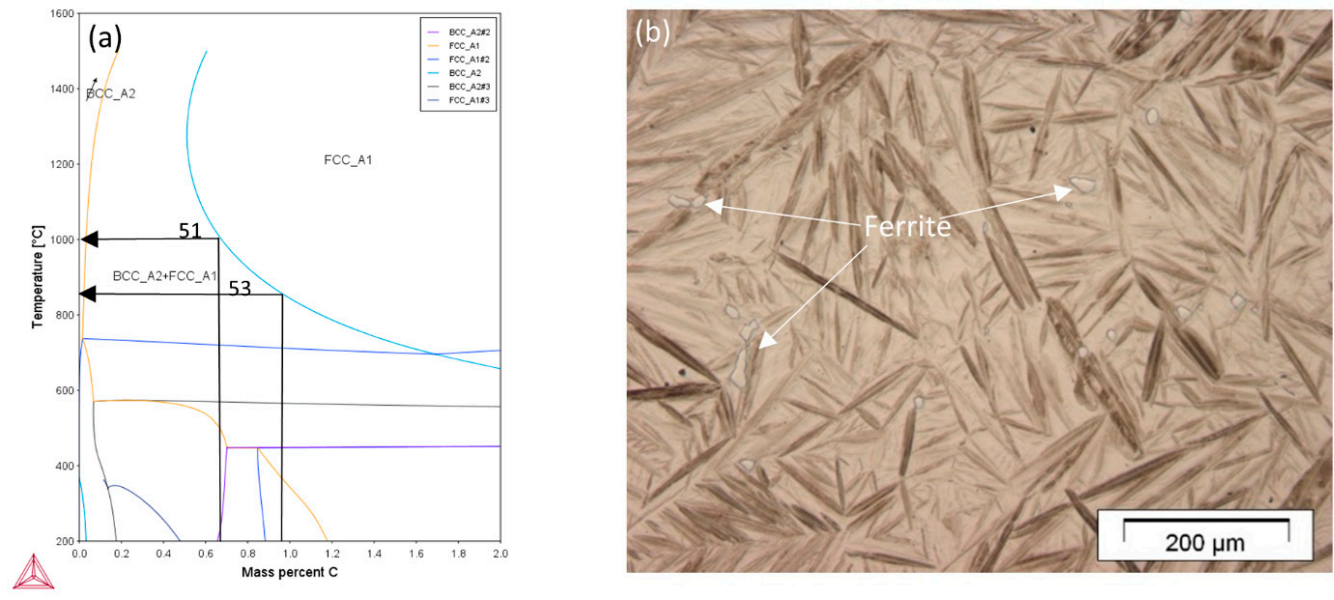

Figure 2. (a) Phase diagram of the 5-group alloy system, (b) Micrograph of alloy 51 after austenitization $\left(1250{ }^{\circ} \mathrm{C} / 15 \mathrm{~min}\right)$ followed by quenching to room temperature.

Accordingly, different austenitization temperatures are used throughout this study. The dilatometry specimens were heated at a rate of $10 \mathrm{Ks}^{-1}$ up to the austenitization temperatures listed in Table 2 and held for $15 \mathrm{~min}$ at that temperature, followed by quenching with a rate of $100 \mathrm{Ks}^{-1}$ to determine the martensite start (Ms) temperature. The temperature vs. change in length curves during quenching for the studied alloys are shown in Figure 3.

Table 2. Austenitization temperatures used for the alloys investigated.

\begin{tabular}{cc}
\hline Alloy & Austenitization Temperature $\left({ }^{\circ} \mathbf{C}\right)$ \\
\hline 3-Group & 950 \\
51 & $1150(10$ vol. $\%$-ferrite $)$ \\
52 & 1200 \\
53 & 1250 \\
\hline
\end{tabular}
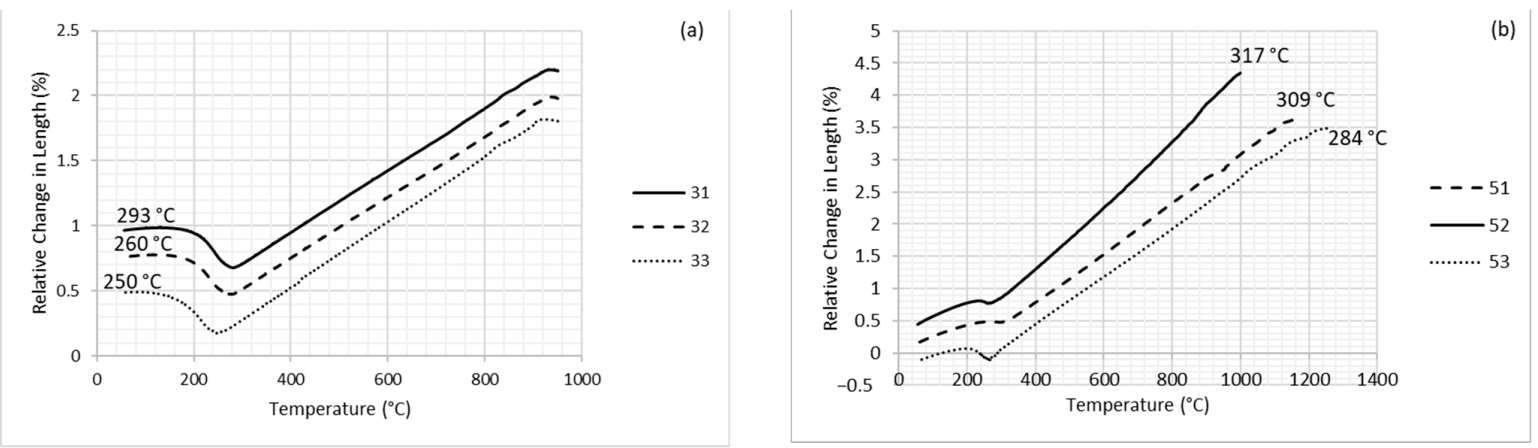

Figure 3. Dilation vs. temperature curves during quenching for (a) 3-group alloys and (b) 5-group alloys. 
The change in length vs. temperature curves along with Ms temperatures for the threeand five-group alloys are presented in Figure $3 a, b$, respectively. Consequently, different austempering temperatures were selected above the measured Ms, as listed in Table 3.

Table 3. Austempering temperatures employed in the study.

\begin{tabular}{ccccccc}
\hline Alloy & Ms $\left({ }^{\circ} \mathbf{C}\right)$ & \multicolumn{5}{c}{ Transformation Temperature $\left({ }^{\circ} \mathbf{C}\right)$} \\
\hline 31 & 293 & - & - & 295 & 310 & 350 \\
32 & 260 & 265 & 280 & 295 & 310 & 350 \\
33 & 250 & 265 & 280 & 295 & 310 & 350 \\
51 & 309 & - & - & - & - & 350 \\
52 & 317 & - & - & - & - & 350 \\
53 & 284 & - & - & 295 & 310 & 350 \\
\hline
\end{tabular}

Figure 4a-f shows LOM images of dilatometric specimens used for determining Ms, which were metallographically prepared to reveal the prior austenite grains. As evident from the LOM images as well as the grain size vs. austenitization temperature curve provided in Figure $4 \mathrm{~g}$, the grain size remains around $50 \mu \mathrm{m}$ up to an austenitization temperature of $1150^{\circ} \mathrm{C}$ and then jumps to around $250 \mu \mathrm{m}$ when the austenitization temperature is increased beyond $1200^{\circ} \mathrm{C}$.
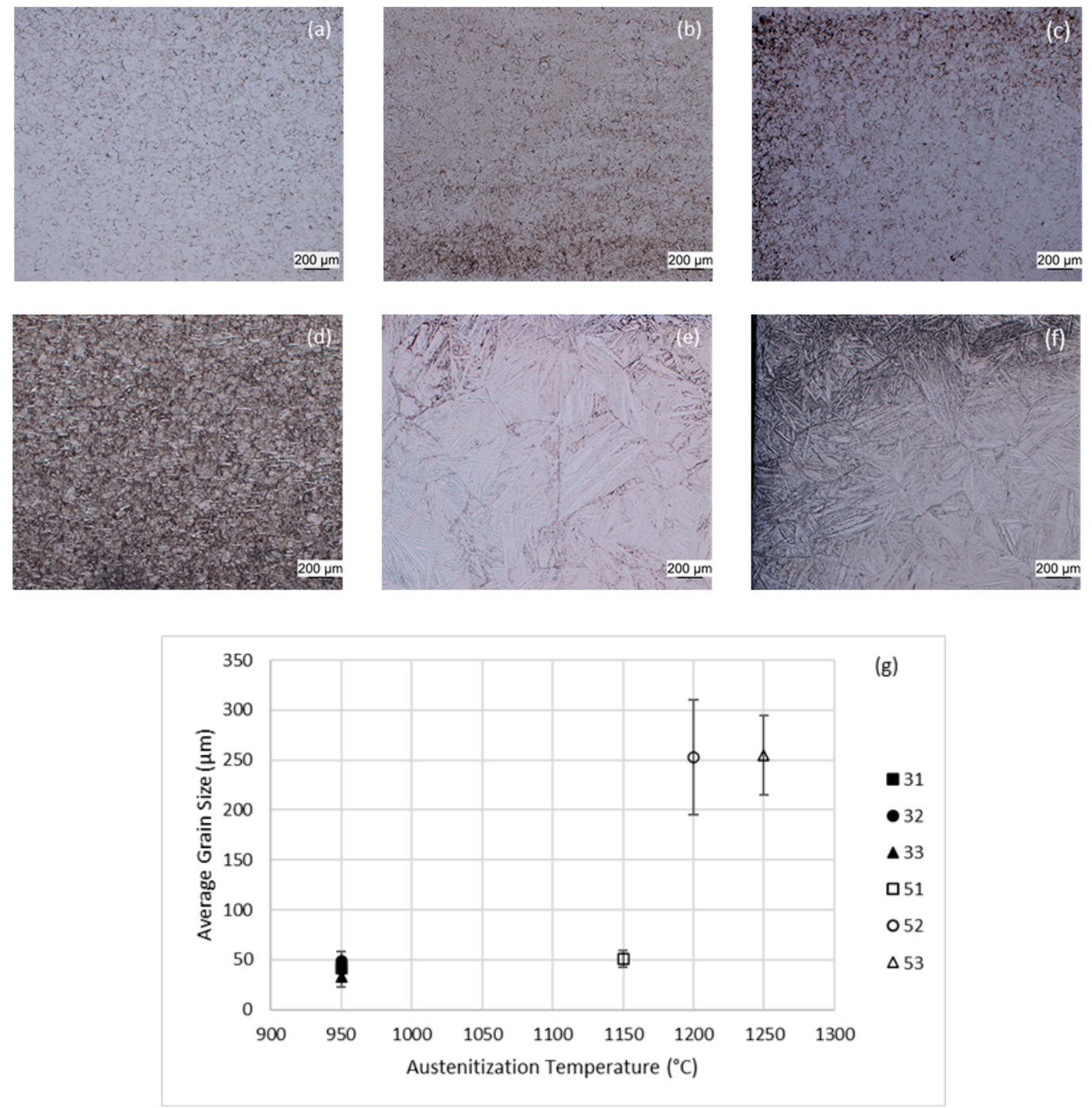

Figure 4. LOM images of (a) 31, (b) 32, (c) 33, (d) 51, (e) 52, (f) 53 showing prior austenite grains, and (g) prior austenite grain size vs. austenitization temperature. 
The evaluation of isothermal bainitic transformation times is essential for research aiming to accelerate the bainitic transformation. However, the determination of exact transformation times using dilatometry is highly dependent on the personal assessment of the researchers involved and, consequently, large variations in estimations between different researchers are to be expected. Hence, a clear criterion for the assessment of the bainitic transformation time needs to be established for this work. Xu et al. [34] suggested the use of the derivative of the dilation vs. time curve to evaluate the transformation time. The time to reach the maximum transformation rate was employed to describe the speed of the transformation. Additionally, $\mathrm{Xu}$ et al. mentioned that after the maximum transformation rate is reached, the rate slows down until it approaches zero, and small amounts of new bainite may keep forming the longer the transformation time is increased. However, this small amount of new bainite could be neglected, as it would have an insignificant effect on the properties of the final alloy, and it would also hinder the commercial feasibility of the alloy in question. A holding time of twice the duration required to reach the maximum transformation rate was suggested as a suitable holding time resulting in most of the microstructure transforming into bainite [34].

Figure 5 illustrates the methodology used to determine the transformation times reported in this work using an example of the 53 alloy isothermally transformed at $310{ }^{\circ} \mathrm{C}$. The dilation rate, which describes the rate of bainitic transformation, was obtained from the derivative of the relative change in length with respect to time. The time of the maximum transformation rate as well as twice this time duration are marked on the figure. As illustrated in Figure 5, a holding time of twice that required to reach the maximum transformation rate was found to be too early during the bainitic reaction to consider that the transformation is over. Hence, the transformation finish time in this study was selected to be the point where the rate of dilation (transformation rate) approaches zero. While the research team is aware that this method is also subject to personal assessment of the individuals analyzing the dilatometric results, the expected deviations should amount to an insignificant amount of new bainite that, as mentioned in [34], should present a negligible effect on the final properties.

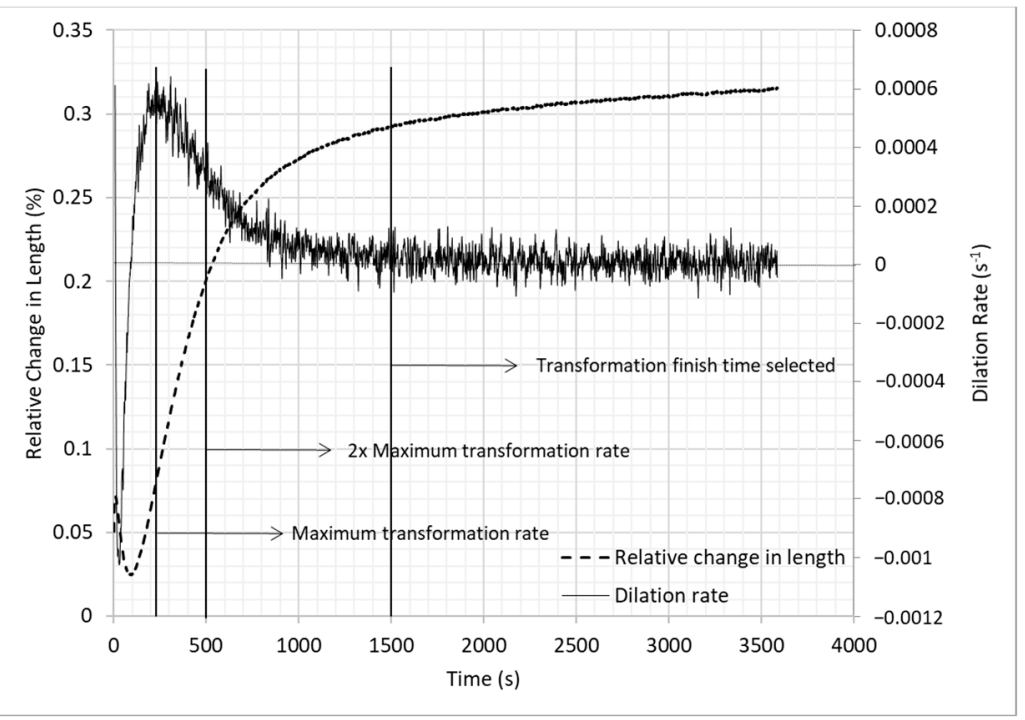

Figure 5. Relative change in length and dilation rate vs. time for the 53 alloy isothermally treated at $310^{\circ} \mathrm{C}$.

The relative change in length with time curves and TTT curves of the conditions investigated are shown in Figures 6 and 7, respectively. Transformation times ranging from 1000 to $4600 \mathrm{~s}$ were recorded for all the alloys investigated. The relatively short bainitic transformation times illustrate the success of the alloying strategies employed in generating fast transforming bainitic alloys. In case of the three-group alloys, Figure 7 
illustrates that both the incubation period as well as the transformation time tend to increase with decreasing austempering temperatures, owing to the retardation of diffusion. Additionally, an increasing C content (31 to 33) also leads to longer transformation times, as $C$ is an austenite stabilizer that retards the transformation. Additionally, the five-group alloys recorded the lowest incubation periods (of 10-30 s). It should be noted that the 53 alloy recorded both shorter incubation periods and faster transformation times than those recorded by the 32 alloy, which has a lower C content ( 0.84 vs. $0.94 \mathrm{wt} . \%)$, which could be attributed to the effect of $\mathrm{Al}$ in increasing the driving force for bainite transformation. Additionally, a finer prior $\gamma$ grain size is reported in the literature to accelerate the bainitic transformation [8,35]. The implication of this is that the larger prior $\gamma$ grain size of the 52 and 53 alloys, while being a drawback of their alloying strategy, is successfully counteracted by the accelerating effect of the $5 \mathrm{wt} . \% \mathrm{Al}$, leading to transformation times faster than the three-group with finer prior $\gamma$ size. These results indicate that an increase in $\mathrm{Al}$ from 3 to $4.75 \mathrm{wt} . \%$ counteracts the retardation caused by the extra $C$ required to maintain a low Ms, as well as the larger prior $\gamma$ grain sizes resulting from the necessary high temperature austenitization, hence leading to an overall successful acceleration of the bainite transformation kinetics.
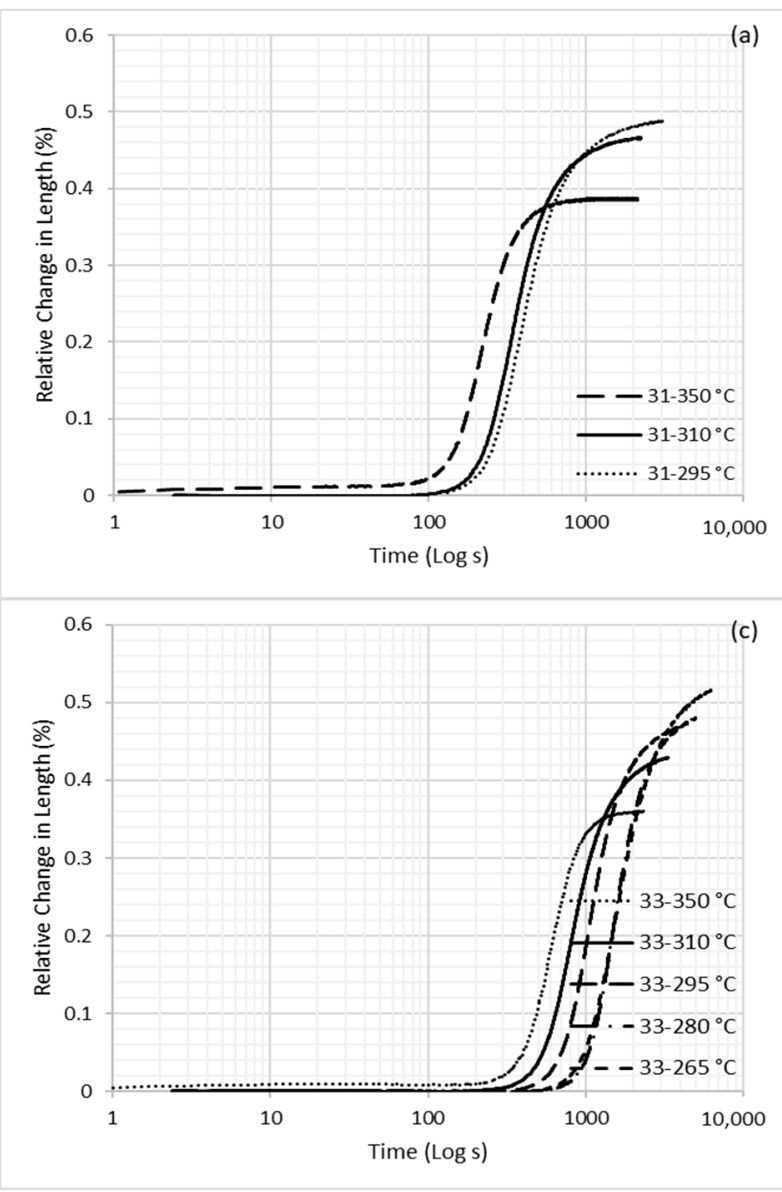
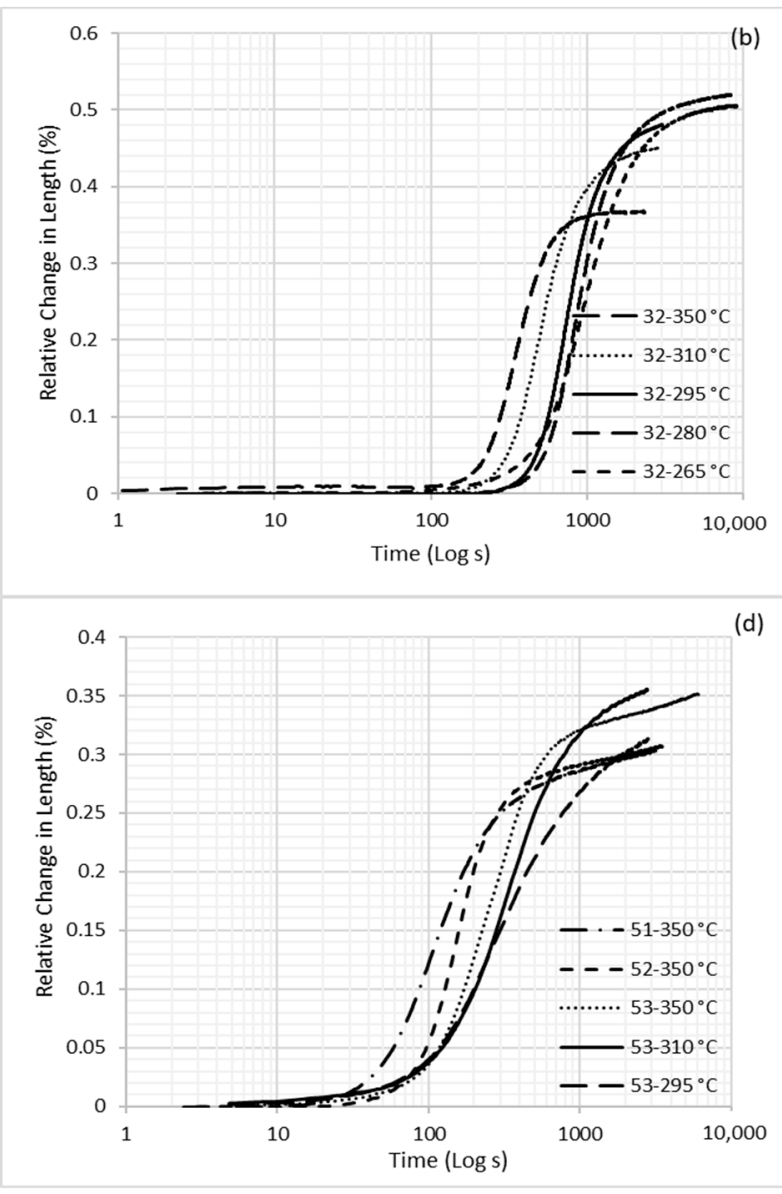

Figure 6. Dilation vs. time curves for (a) 31 alloy, (b) 32 alloy, (c) 33 alloy, (d) 5-group alloys.

Figure 8 shows the SEM and TEM micrographs of selected conditions from the alloys investigated. The microstructures consist of the usual bainitic ferrite and retained austenite in both film and blocky forms. Alloy 51 (Figure 8a) also includes large $\delta$-ferrite grains. Additionally, the larger $\gamma_{\mathrm{r}}$ grains are expected to contain martensite at their centers; however, this would be undetectable via the microscopy techniques used. Additionally, no carbide precipitates were detected during the TEM investigations. 


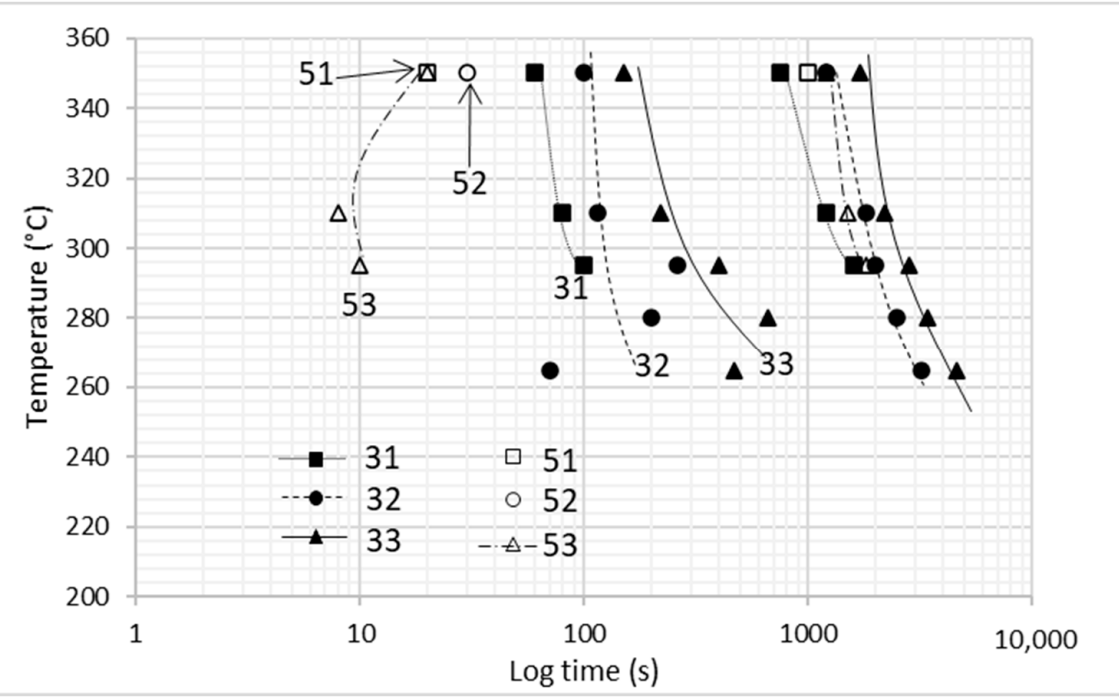

Figure 7. TTT curves of the alloys investigated.
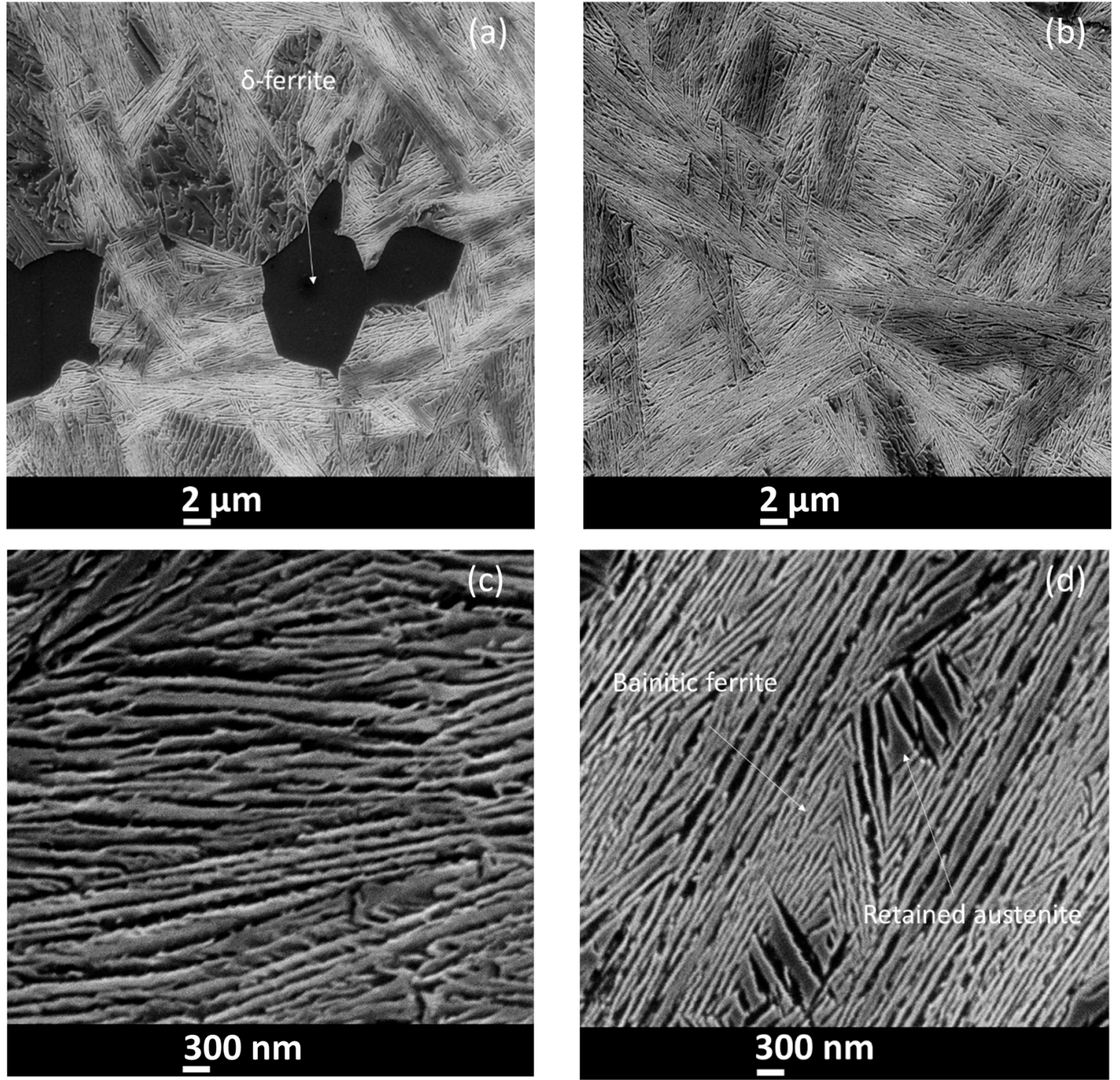

Figure 8. Cont. 

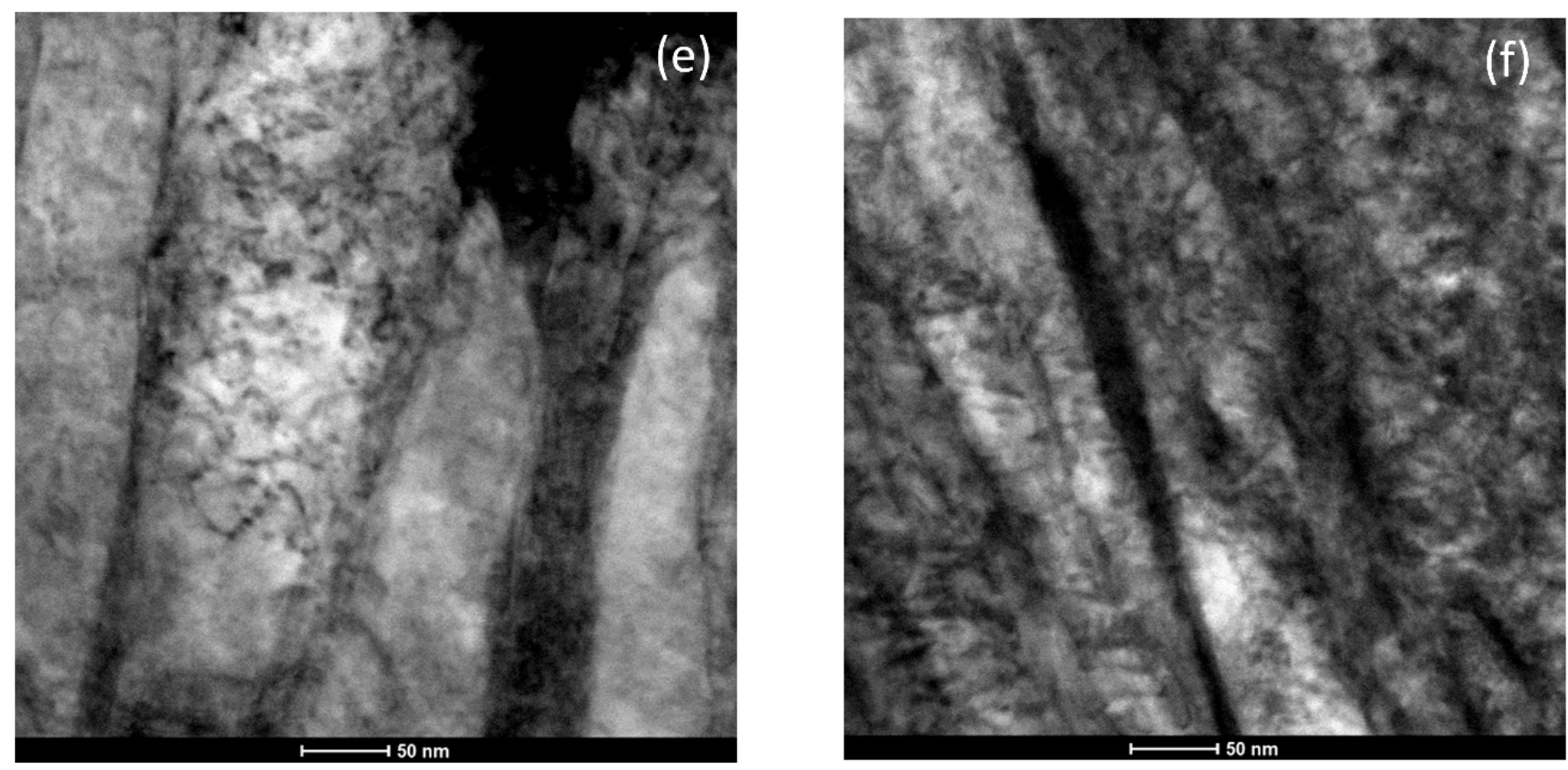

Figure 8. SEM images of (a) 51 T350, (b) 52 T350, (c) 33 T310, (d) 53 T310, and TEM images of (e) 53 T310 and (f) 33 T265 showing bainitic lamellae.

Figure 9 shows EDX maps of the substitutional alloying elements in alloy 33, which was austenitized at the lowest temperature of $950{ }^{\circ} \mathrm{C}$, and alloy 53, which was austenitized at the highest temperature of $1250^{\circ} \mathrm{C}$. The EDX mapping results indicate an absence of segregation along the prior austenite grain boundaries, this is a result of the aforementioned homogenization treatment at $1100{ }^{\circ} \mathrm{C}$ for $48 \mathrm{~h}$. EDX mapping as well as line-scan analysis across prior austenite grain boundaries detected a homogenous distribution of substitutional elements (save for the occasional MnS or AlN particle such as in Figure 9f-h). Since no segregation has been detected, and, consequently, none of its effects are expected to influence the current investigation, only two specimens representing the lowest and highest austenitization conditions are presented as an example in Figure 9.
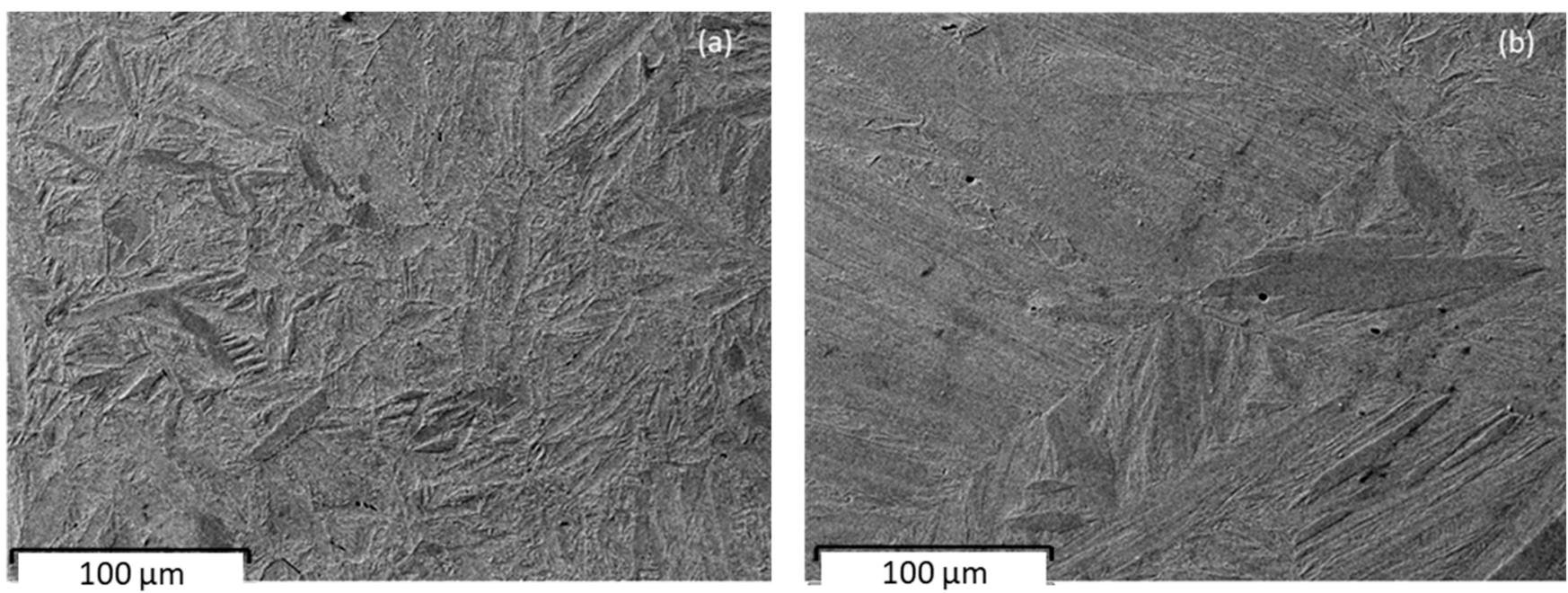

Figure 9. Cont. 


\section{Si K $\alpha 1$}

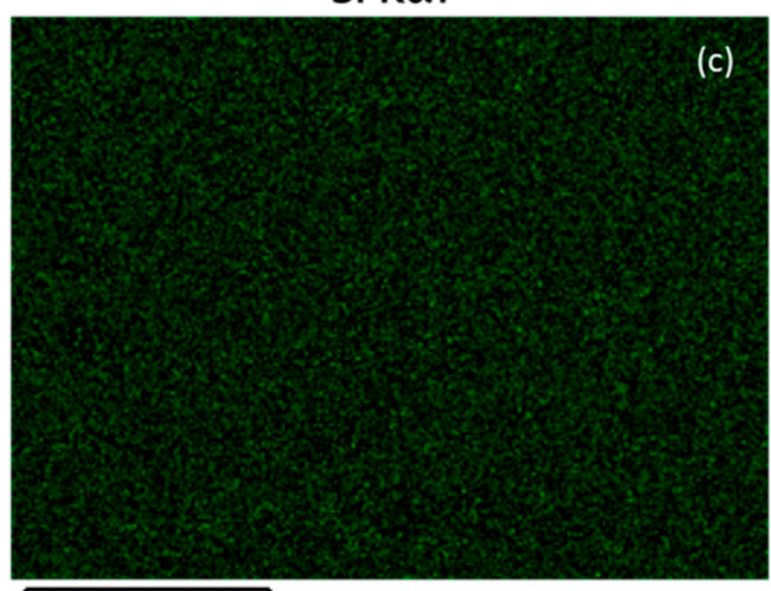

$100 \mu \mathrm{m}$

Al K $\alpha 1$

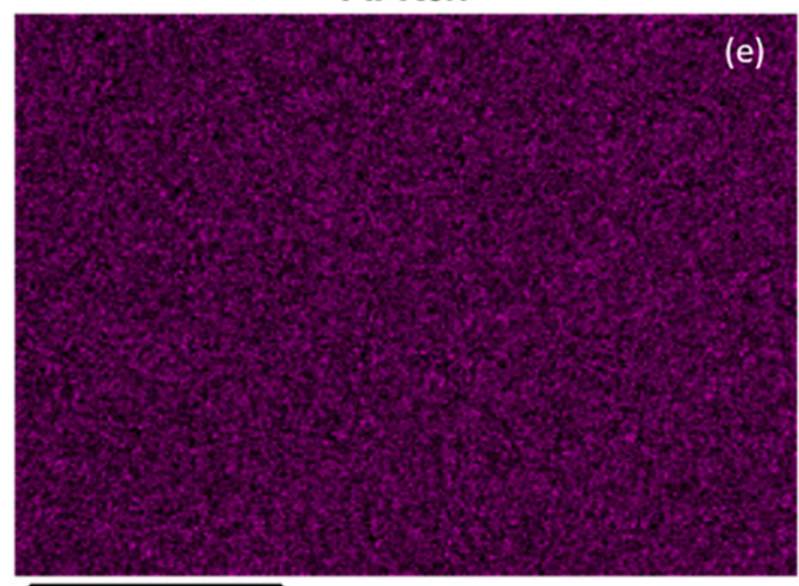

$100 \mu \mathrm{m}$

$M n K \alpha 1$

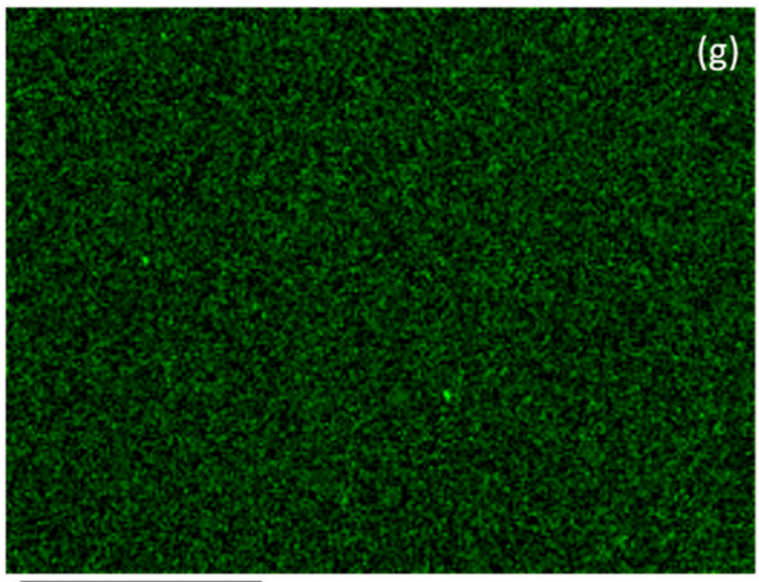

$100 \mu \mathrm{m}$
Si K $\alpha 1$

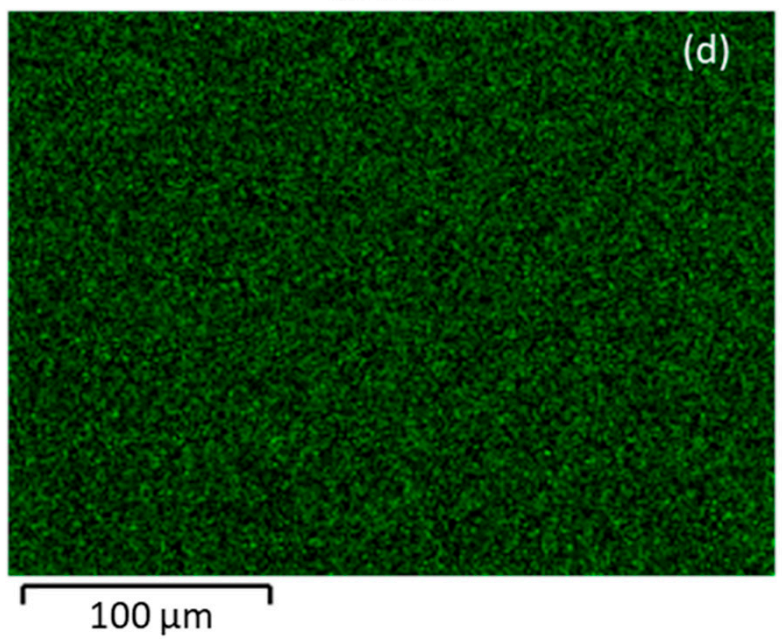

Al K $\alpha 1$

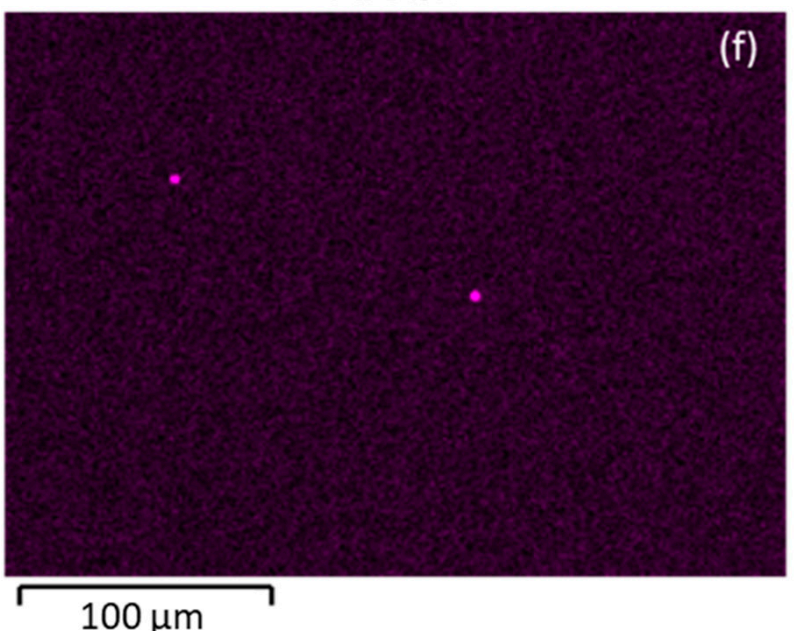

$M n K \alpha 1$

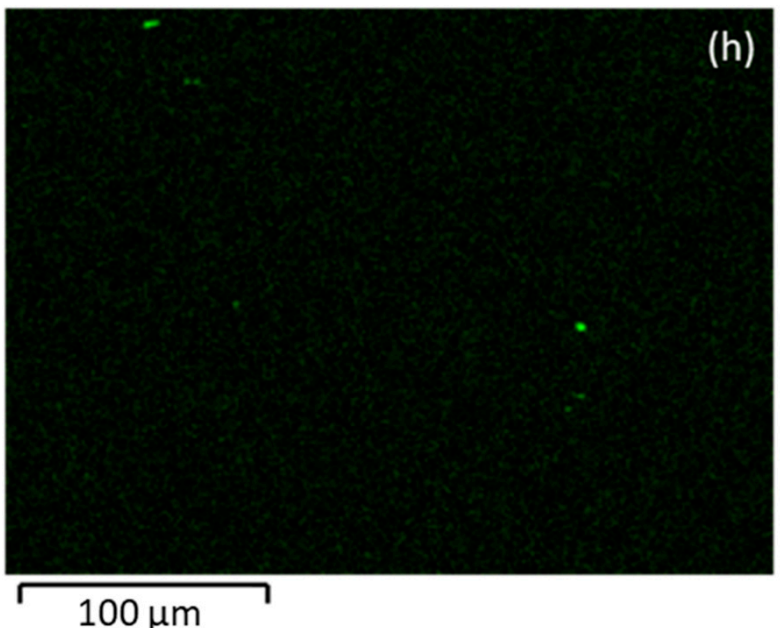

(h)

Figure 9. (a) SEM image of the 33 alloy, (b) SEM image of the 53 alloy, and EDX mapping of (c) Si in 33, (d) Si in 53, (e) $\mathrm{Al}$ in 33, (f) $\mathrm{Al}$ in 53, (g) Mn in 33, (h) Mn in 53. 


\subsection{Mechanical Behavior}

The tensile strength results shown in Figure 10a indicate a linear increase in tensile strength as the transformation temperature is decreased, with strength values ranging from 1330 to $1995 \mathrm{MPa}$. Alloy 51 recorded the lowest tensile strength value of $1330 \mathrm{MPa}$, owing to the presence of $10 \mathrm{vol} . \% \delta$-ferrite in its microstructure. Alloy 53 outperforms the three-group alloy in terms of tensile strength at the lower transformation temperatures of 310 and $295{ }^{\circ} \mathrm{C}$. On the other hand, at $350{ }^{\circ} \mathrm{C}$, the tensile strengths of the alloys 31 and 32 were the highest among all the alloys studied. Additionally, when observing the tensile strength results presented in Figure 10a for the three-group at 350 and $310{ }^{\circ} \mathrm{C}$, it appears that the tensile strength decreases with an increasing $C$ content, with alloy 31 recording the highest strength at 350 and $310^{\circ} \mathrm{C}$, followed by alloy 32 , and with the lowest strength value recorded by alloy 33 . On the other hand, with a decreasing austempering temperature the differences in strength caused by differences in the $\mathrm{C}$ content start to decrease, with the alloys recording very similar strength values at 295,280 and $265^{\circ} \mathrm{C}$. Garcia-Mateo and Caballero report that the main strengthening contributor in the $\mathrm{nB}$ microstructure is the bainitic lamellar thickness, hence, at lower temperatures, where the lamellar thickness is finest, higher tensile strengths are expected [36]. Plotting the change in lamellar thickness against the $C$ content (Figure 10b) further reinforces the aforementioned trends in tensile strength, showing that the lamellar thickness decreases both with the decreasing transformation temperature and $\mathrm{C}$ content. These findings are in line with the available literature on the topic $[8,20]$. Figure $8 \mathrm{f}$ shows the higher dislocation density of the bainitic ferrite, associating with performing the transformation at a lower temperature of $265^{\circ} \mathrm{C}$ compared to that developed at $310^{\circ} \mathrm{C}$ (Figure 8e).

Singh and Bhadeshia used neural networks to determine the factors influencing bainitic lamellar thickness. It was found that the most significant factor affecting lamellar thickness was the strength of austenite, followed by the driving force for transformation, with temperature only playing an indirect role by affecting both effects [37]. Al, in itself, is not a solid solution strengthening element; however, increasing the $\mathrm{Al}$ content can indirectly strengthen the $\mathrm{nB}$ steel via increasing the driving force for bainite formation and, thus, refining the bainite platelets in the microstructure [38]. The change in Gibb's energy $(\Delta G)$ for the transformation from austenite to ferrite vs. temperature curves for the alloys studied is presented in Figure 10c. The highest driving force values are illustrated for 31,51 , and 52, implying that lowering the $C$ content has an effect as significant as that of increasing that of Al. Contrary to the expected, the driving force values for alloy 53 were found to be the lowest, which contradicts both its fast transformation time results, as well as its fine lamellar thickness and consequently high tensile strength. As previously mentioned, the austenite strength as well as driving force govern the lamellar thickness of bainitic microstructures. The results presented in Figure 10, however, imply that the dominant factor changes with changing transformation temperatures, with lower $\mathrm{C}$ alloys (higher driving force) are favored at higher transformation temperatures, while the high Al 53 alloy (higher austenite strength due to higher $C$ content) becomes more favored with temperatures lowered to 310 and $295^{\circ} \mathrm{C}$. This also explains why the differences in tensile strength among alloys of the same group become less noticeable with reduced transformation temperatures, as the difference in driving force caused by the difference in C content becomes less relevant. However, the high Al strategy being more effective at lower austempering temperatures in itself could be considered as a drawback. The effect of $\mathrm{Al}$ on lowering the hardenability of steel leads to an increase in its Ms, consequently limiting it to higher austempering temperatures around $300^{\circ} \mathrm{C}$. Another factor to consider concerning the bainitic lamellar thickness is the effect of the prior $\gamma$ grain size. Conflicting reports exist in the literature regarding the effect of prior $\gamma$ grain size on bainitic lamellar thickness, with some sources reporting that a smaller prior $\gamma$ led to lamellar thickening due to impingement hindering growth [39], while others report it as having a refining effect owing to the enhanced number of nucleation sites [35]. However, discrepancies in the experimental results of the $\gamma_{\mathrm{r}}$ obtained in this investigation (presented below in Figure $9 \mathrm{~b}$ ) 
and the effects of a larger prior $\gamma$ size reported in [39] imply that the more likely effect of the prior $\gamma$ grain size on lamellar thickness is that presented in [35].
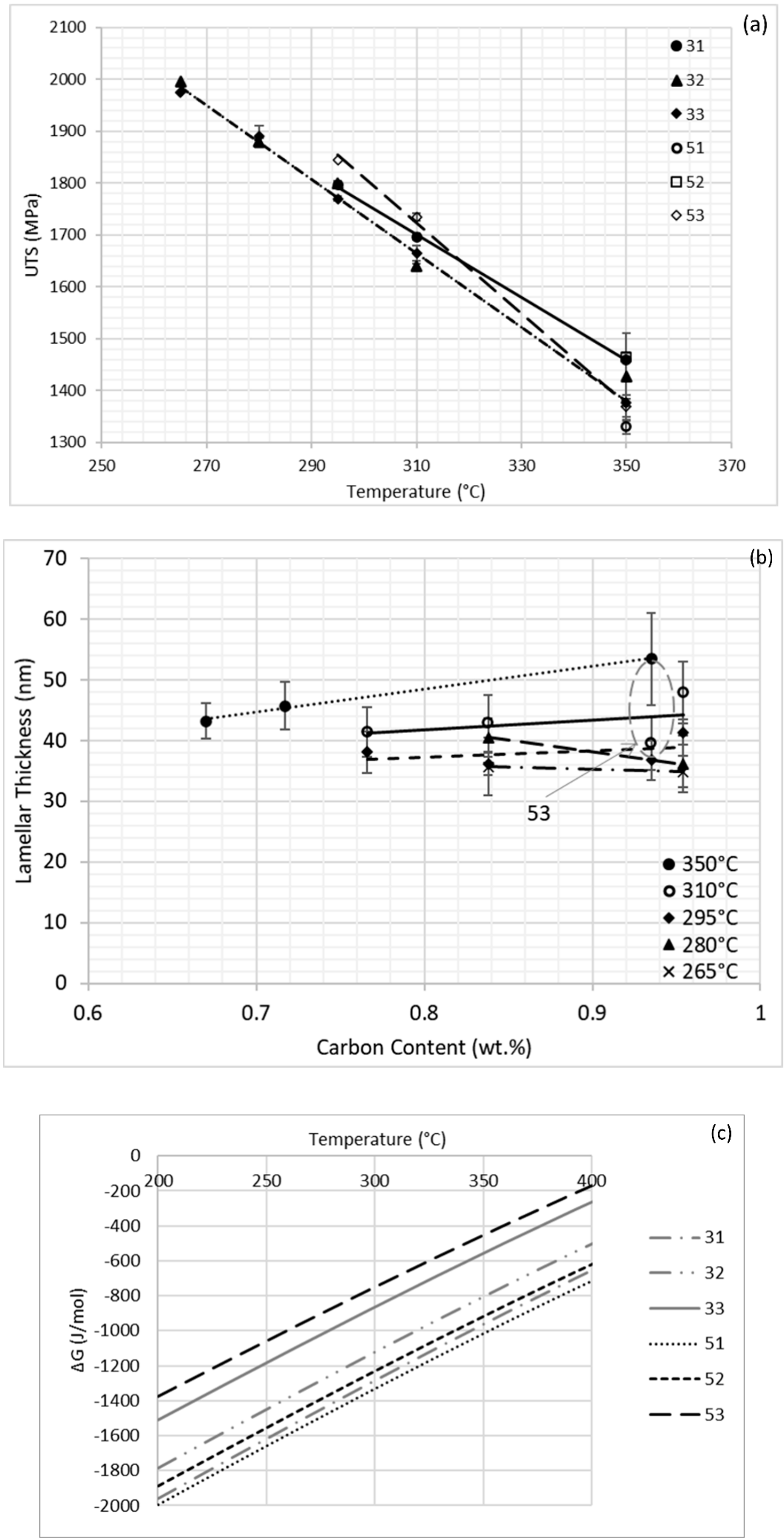

Figure 10. (a) Variation of UTS with austempering temperature, (b) Variation of bainitic lamellar thickness with carbon wt.\%, (c) Change in $\Delta \mathrm{G}$ values for the transformation from austenite to ferrite vs. transformation temperature simulated using ThermoCalc. 
The total elongation (EL\%) results presented in Figure 11a show a slight drop in their values associated with austempering at lower temperatures. The EL\% values for the fivegroup are significantly lower than those recorded for the three-group, with the exception being alloy 51, owing to the presence of the soft $\delta$-ferrite phase in its microstructure. The ductility properties of $\mathrm{nB}$ microstructures are usually governed by the amount and morphology of retained austenite in the microstructure. Plotting the EL\% vs. the retained austenite values obtained from the XRD measurements, see Figure 11b, indicates that the five-group alloys have higher retained austenite contents in comparison to the three-group. This is in contradiction with some of the present sources on the effect of prior $\gamma$ size on the amount of $\gamma_{\mathrm{r}}$, where an increase in the $\gamma$ size is associated with a lower fraction of $\gamma_{\mathrm{r}}$ [39]. It is evident that the results are clustered around two values, with the $3 \mathrm{wt} . \% \mathrm{Al}$ alloys (as well as the 10 vol. $\% \delta$-ferrite in alloy 51 ) recording an EL\% of around $10 \%$, and the 5 wt. $\%$ $\mathrm{Al}$ alloys recording an EL\% of around 5\%. According to the available nB literature, EL\% values of around $5 \%$ are considered the lower limit for $\mathrm{nB}$ alloys $[4,11,14,40,41]$.
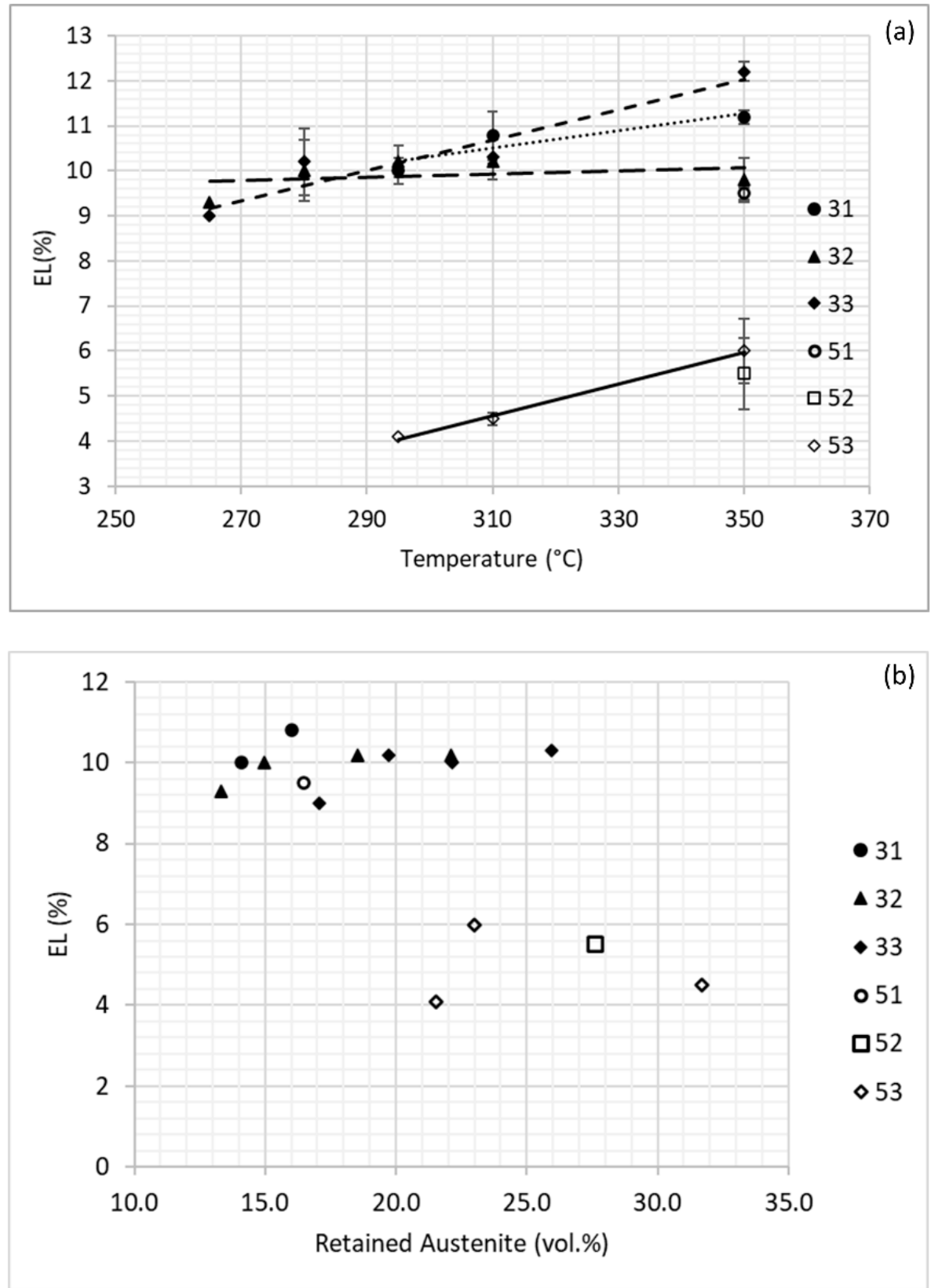

Figure 11. Cont. 

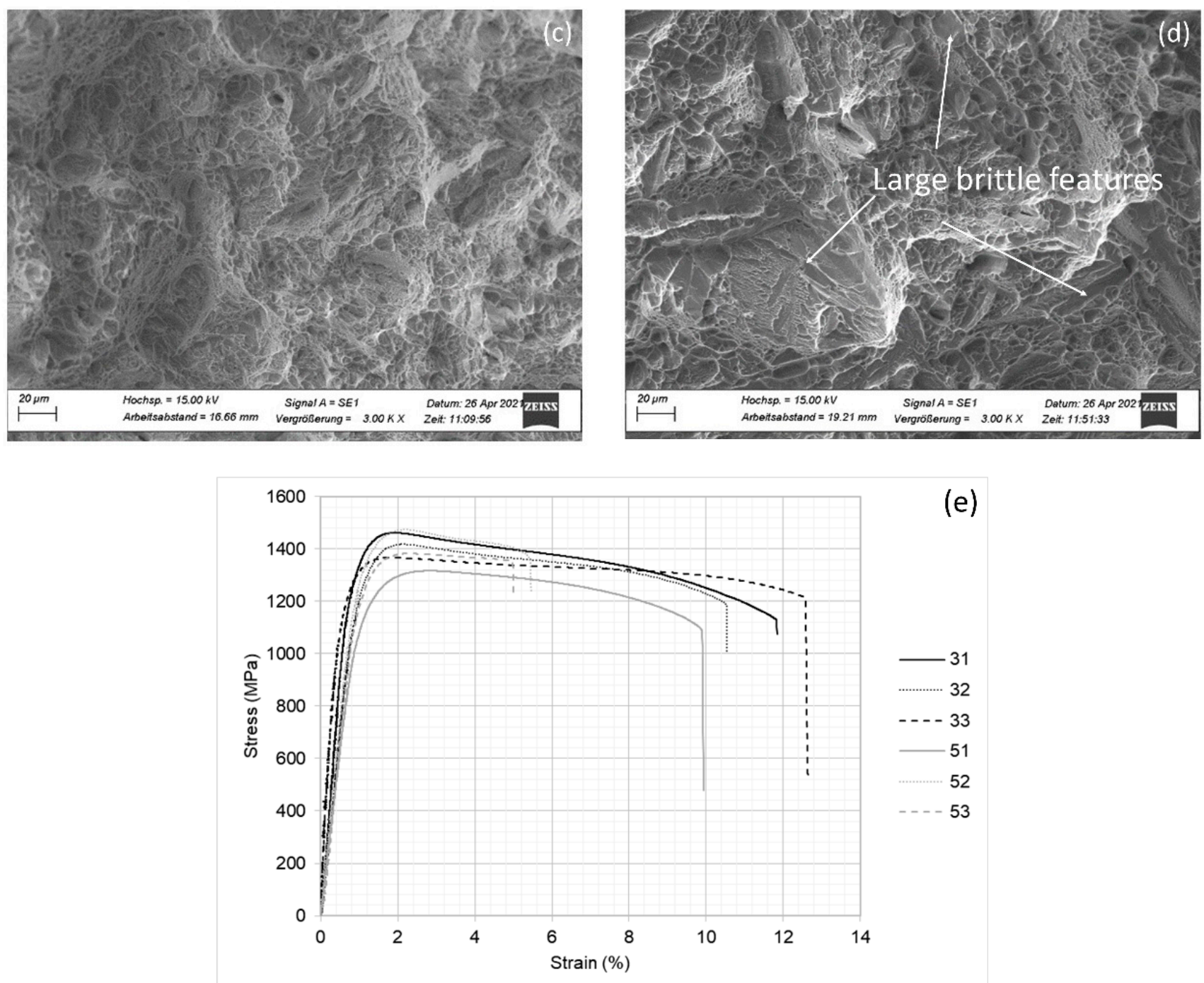

Figure 11. Variation of EL\% with (a) Austempering temperature, (b) Retained austenite volume percentage, SEM micrographs of fracture surfaces of a (c) 33 tensile specimen, (d) 53 tensile specimen after austempering at $310{ }^{\circ} \mathrm{C}$ and tensile testing, and (e) Stress-strain curves of the 3- and 5-group alloys austempered at $350{ }^{\circ} \mathrm{C}$.

Conventionally, adverse effects on the ductility of $\mathrm{nB}$ alloys are caused by a large amount of unstable blocky austenite grains, which prematurely transform to martensite upon the application of low loads. However, in the present case, the most significant factor limiting the EL\% seems to be the $\mathrm{Al}$ content; increasing the Al-content from $\sim 3$ to $\sim 5 \mathrm{wt} . \%$ decreased the $\mathrm{El} \%$ from $\sim 10$ to $\sim 5 \%$. Al is an alloying element that increases the driving force for ferrite transformation, this has both direct and indirect effects on the stability of austenite. The first is the direct effect of lowering the stability of the austenite relative to ferrite, lowering the stability of any retained austenite grains in the microstructure. The second effect is a result of the increase in Ms brought about by the $\mathrm{Al}$ addition, which necessitates a higher $\mathrm{C}$ content in the alloys, consequently leading to a higher amount of unstable blocky austenite in the final microstructure. This increase in the amount of blocky austenite, coupled with its lowered stability due to the presence of high $\mathrm{Al}$ contents, leads to a significant portion of the microstructure transforming to brittle martensite at low loads, hence, deteriorating its ductility. The stress-strain curves presented in Figure 11e illustrate a very brief strain hardening stage for both the three- and five-group alloys, which imply the presence of unstable blocky austenite in both. On the other hand, the tensile fracture surfaces (Figure $8 c$,d) show that, contrary to the fine dimple pattern that characterizes the 
fracture surface of the 33 alloy, the fracture surface of the 53 alloy displays large features that indicate cleavage fracture. These larger features are most likely the aforementioned blocky $\gamma$ grains that turned to brittle martensite during tensile testing, implying that the size of the blocky $\gamma$ formed, rather than their stability in the five-group alloys, is the main factor causing their low ductility.

The variation of the impact energy with austempering temperature shown in Figure 12 displays the expected trend of impact energy dropping with the transformation temperature. Contrary to tensile properties, the bainitic lamellar thickness does not play a major role in governing the impact properties. Displacive microstructures-such as martensite and bainite-are reported to rely mainly on their prior $\gamma$ grain size when it comes to impact properties $[42,43]$. The influence of prior austenite grain size on impact properties is apparent in Figure 10. The 53 alloy recorded lower impact energy values compared to the three-group. Additionally, the 52 alloy austempered at $350{ }^{\circ} \mathrm{C}$ recorded impact properties comparable to those of the three-group austenitized at $310^{\circ} \mathrm{C}$. The low impact properties of the 52 and 53 alloys can be attributed to their much larger prior $\gamma$ grain size of $250 \mu \mathrm{m}$ compared to the $50 \mu \mathrm{m}$ of the three-group. A notable difference between the impact testing results and the tensile testing results is that alloy 51, despite its lower prior $\gamma$ grain size of $50 \mu \mathrm{m}$, underperforms compared to the impact testing results of alloy 52 . The presence of $\delta$-ferrite grains (Figure 8a) is well reported in the literature to have an adverse effect on the impact properties of steel alloys [44,45], giving an argument for the lower impact properties of 51 compared to 52 .

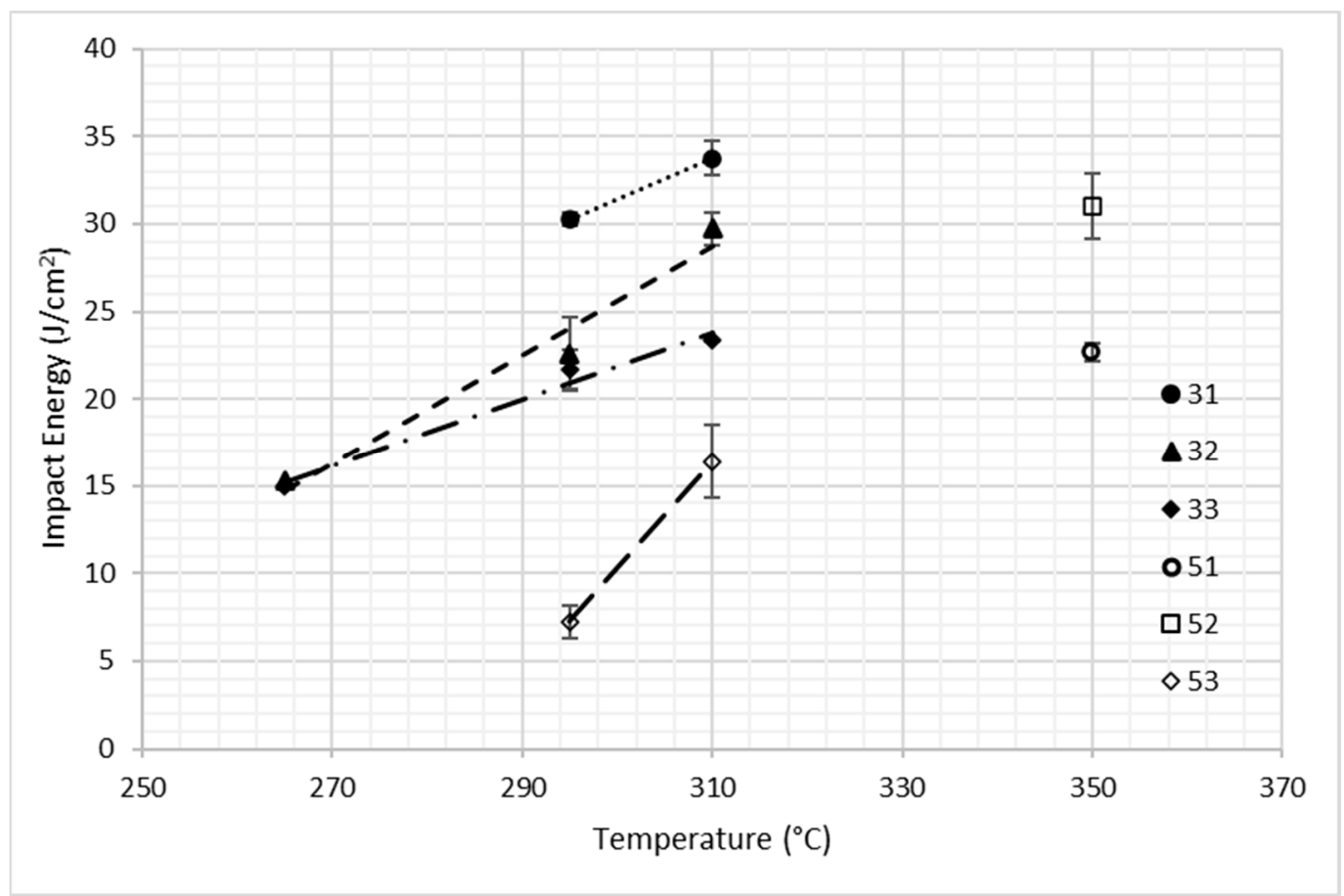

Figure 12. Variation of impact energy with austempering temperature.

Figure $13 a, b$ show the $T_{0}$ curves for the two alloy systems studied. The $T_{0}$ curve is the locus of all the points where the stabilities of ferrite and austenite are equal for the same carbon content, and hence beyond it no bainite transformation occurs. The actual $\gamma_{\mathrm{r}} \mathrm{C}$ content calculated from the synchrotron XRD analysis overshoots the theoretical $\mathrm{T}_{0}$ curve; this is a common phenomenon in $\mathrm{nB}$ steels attributed by Bhadeshia and Edmonds to the inhomogeneous distribution of $C$ between the film and the blocky austenite [46]. The measured austenite $C$ contents for both groups exceed the theoretically calculated ones, albeit that the results of the five-group deviate even further from the theoretical values than those of the three-group. There are two conclusions to infer from Figure 10. 
Firstly, as mentioned earlier in this paragraph, a deviation between the measured and the theoretical austenite $\mathrm{C}$ contents in an $\mathrm{nB}$ alloy is indicative of the instability of its blocky austenite, suggesting that a portion of it would transform to martensite after austempering upon cooling to room temperature, and a higher deviation in the five-group suggests a higher amount of unstable blocky austenite. A significant amount of retained austenite transforming to martensite upon cooling coupled with the already high retained austenite amount detected in the five-group via XRD testing would explain its significantly low ductility. Secondly, by observing the $T_{0}$ curves in Figure $10 \mathrm{a}, \mathrm{b}$, as well as the $\Delta \mathrm{G}$ values provided in Figure 10c, it is apparent that the thermodynamic simulation performed using ThermoCalc's TCFE9 database tends to overestimate the effect of $C$, while underestimating the effect of $\mathrm{Al}$ on both the Gibb's energy as well as the equilibrium $\mathrm{C}$ content presented by the $\mathrm{T}_{0}$ curve.
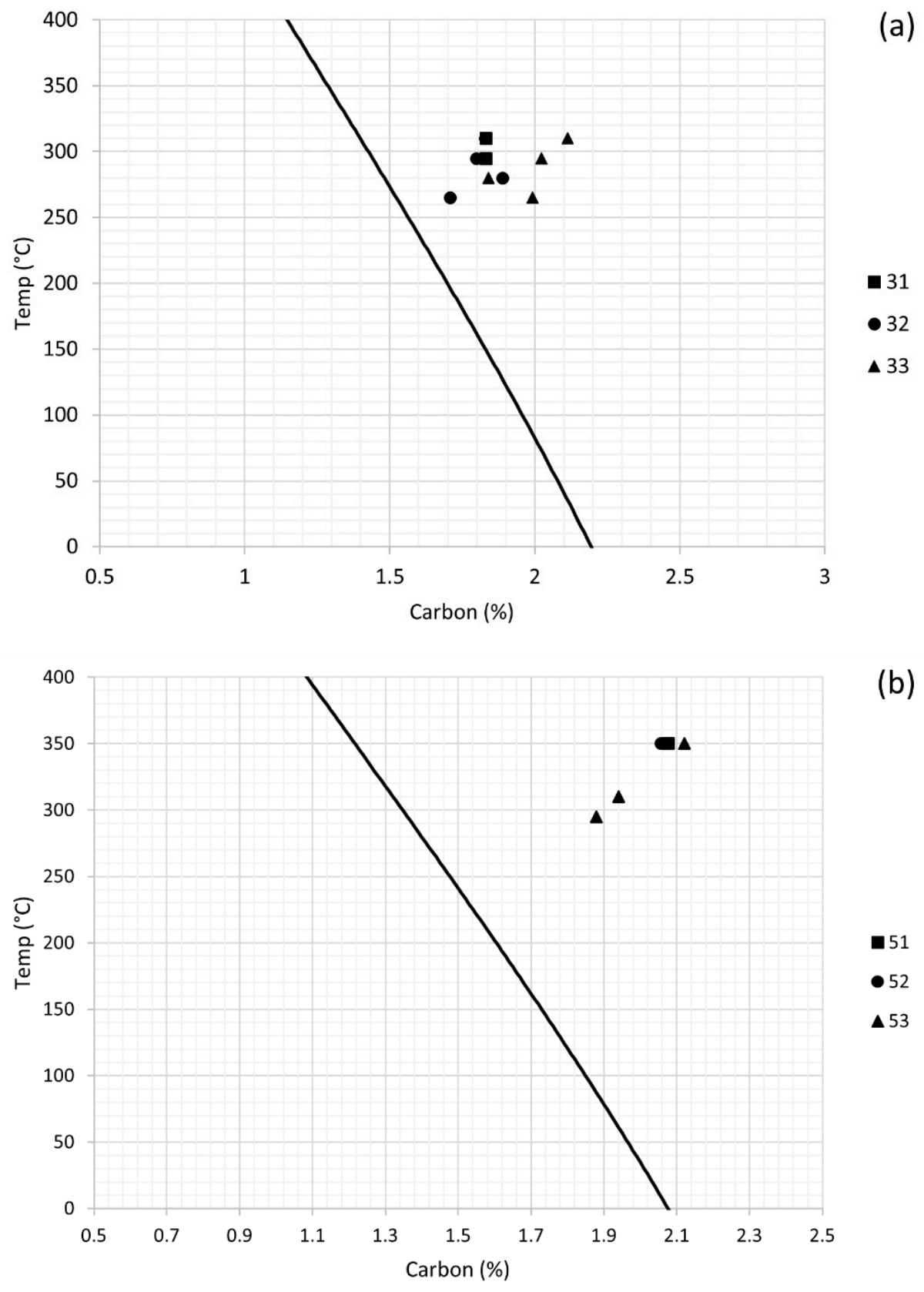

Figure 13. $\mathrm{T}_{0}$ curves of (a) 3-group alloy system, (b) 5-group alloy system. 


\section{Discussion}

Conflicting findings were observed when comparing the thermodynamic simulations with the experimental results obtained, as well as the information on the effect of $\mathrm{Al}$ on $\mathrm{nB}$ microstructures in the available literature. While the possibility exists that the TCFE9 database for ThermoCalc fails to accurately predict the effect of unconventionally high $\mathrm{Al}$ contents on the microstructure, it is also plausible that the effects do not vary linearly with the $\mathrm{Al}$ content. Additionally, complex interactions could take place, caused by other factors needed for a successful $\mathrm{nB}$ alloy with high $\mathrm{Al}$ content (higher hardenability element content, higher Ms and austempering temperature).

An increase in the $\mathrm{Al}$ content from 3 to $5 \mathrm{wt}$.\% led to an acceleration in the transformation time as well as an increase in the tensile strength and a refinement of the bainitic lamellar thickness, at least in the case of the 53 alloy, this is also despite the negative effect of its larger prior austenite grain size on the transformation kinetics. The aforementioned effects imply an increase in the driving force for austenite transformation to bainite increasing the $\mathrm{Al}$ content. However, contrary to these findings, the thermodynamically simulated driving force values presented in Figure 10c illustrate that the best performing alloy in terms of tensile strength, transformation time, and lamellar thickness (alloy 53) has the lowest driving force among the alloys studied. The figure also implies that the effect of carbon on lowering the driving force is higher than the effect of $\mathrm{Al}$ on increasing it. Additionally, Figure 10a illustrates a tendency for the five-group alloys to attain lower strength values at $350^{\circ} \mathrm{C}$ compared to the three-group, while attaining higher strength than the three-group as the transformation temperature is lowered to 310 and $295^{\circ} \mathrm{C}$. These findings present a drawback for $\mathrm{Al}$ contents ahead of $3 \mathrm{wt} . \%$. While the increase in $\mathrm{Al}$ content up to $5 \mathrm{wt} . \%$ provides benefits to the transformation time and strength at lower austempering temperatures, the increased Ms and low hardenability limit the five-group to high carbon contents as well as high austempering temperatures, making it difficult to utilize the advantage the high Al strategy would have at lower transformation temperatures.

Moreover, it appears that the higher $\mathrm{Al}$ content of the five-group leads to a low stability of retained austenite, since $\mathrm{Al}$ lowers the stability of austenite and under the conditions of para-equilibrium, the retained austenite in an $\mathrm{nB}$ microstructure would have the same substitutional element content (here, $\mathrm{Al}$ is relevant) as the nominal composition of the alloy. While the $\mathrm{T}_{0}$ curves provided in Figure 13a,b indicate a higher measured austenite carbon in the five-group than the three-group, implying lower austenite stability, the values are further distanced from the thermodynamically simulated $\mathrm{T}_{0}$ curve. This discrepancy in simulated and experimentally determined austenite carbon content has a number of implications. The first is that the values are skewed toward the highly supersaturated film austenite, since a large portion of the less stable blocky austenite is expected to transform to martensite upon cooling to room temperature. Additionally, a larger difference between the thermodynamically simulated and experimentally measured austenite carbon contents for the five-group suggests a larger amount of unstable blocky austenite that transforms to brittle martensite after austempering, which would serve to explain the low ductility of the five-group alloys, especially when considering that the five-group alloys also have a higher measured retained austenite content at room temperature. The second implication is that, as Figure 10c illustrates, the effect of $\mathrm{Al}$ on improving both the driving force and the $\mathrm{T}_{0}$ for $\mathrm{nB}$ generation is nonlinear and starts to fall off after additions higher than $3 \mathrm{wt} . \%$. These findings suggest the existence of a local optimum $\mathrm{Al}$ addition around the $3 \mathrm{wt} . \%$ value for fast transforming, high strength, and low cost nB steels.

\section{Conclusions}

A low-cost strategy for accelerating $\mathrm{nB}$ formation through the addition of large amounts of $\mathrm{Al}$ ( 3 and $5 \mathrm{wt} . \%$ ) has been studied. Transformation times less than $4600 \mathrm{~s}$ were recorded for all the alloys, and very short transformation times of 1000-1800 s could be obtained with the addition of $\sim 5 \mathrm{wt} . \%$ Al. The tensile strength values ranged from $1330 \mathrm{MPa}$ for the $5 \mathrm{wt} . \% \mathrm{Al} 5 \mathrm{l}$ alloy with $10 \mathrm{vol} . \%$ delta ferrite up to $2000 \mathrm{MPa}$ for the $3 \mathrm{wt} . \%$ 
Al 33 alloy, while maintaining ductility values of $10 \mathrm{EL} \%$. It was not possible to obtain a ferrite-free microstructure in the former alloy. The tensile strengths of the $5 \mathrm{wt} \% \mathrm{Al}$ alloys were higher than those of the $3 \mathrm{wt}$ \% Al group at the lower transformation temperatures of 310 and $295^{\circ} \mathrm{C}$. On the other hand, the ductility of the alloys studied was hindered by the low stability of the retained austenite in the microstructure, which transformed to martensite upon loading, dropping the EL\% of the $5 \mathrm{wt} . \%$ Al group alloys to around $5 \%$. The results of the mechanical testing and thermodynamic simulation suggest that $\mathrm{Al}$ additions beyond $3 \mathrm{wt} . \%$ are not recommended. The higher Al content lowers the stability of retained austenite, increases the martensite start temperature as well as necessitates austenitization at higher temperatures, leading to prior austenite grain growth. This, in turn, generates nB alloys that, while having fast transformation times and fine lamellar structures, are limited to higher austempering temperatures and suffer from lower ductility compared to their lower Al counterparts.

Author Contributions: M.A.: methodology, validation, formal analysis, investigation, writingoriginal draft, visualization, and project administration. M.S.: conceptualization, methodology, validation, writing - review and editing, supervision, project administration, and funding acquisition. H.P.: resources, writing-review and editing, supervision, and project administration. All authors have read and agreed to the published version of the manuscript.

Funding: This work was funded by the German Research Foundation (DFG), grant number: DFG SO 1250/1. We acknowledge financial support by Open Access Publishing Fund of Clausthal University of Technology.

Institutional Review Board Statement: Not applicable.

Informed Consent Statement: Not applicable.

Data Availability Statement: The raw/processed data required to reproduce these findings cannot be shared at this time as the data also forms part of an ongoing study.

Acknowledgments: We acknowledge financial support by Open Access Publishing Fund of Clausthal University of Technology.

Conflicts of Interest: The authors declare no conflict of interest.

\section{References}

1. Soliman, M.; Palkowski, H. Ultra-fine Bainite Structure in Hypo-eutectoid Steels. ISIJ Int. 2007, 47, 1703-1710. [CrossRef]

2. Zhao, J.; Jia, X.; Guo, K.; Jia, N.N.; Wang, Y.F.; Wang, Y.H.; Wang, T.S. Transformation behavior and microstructure feature of large strain ausformed low-temperature bainite in a medium C-Si rich alloy steel. Sci. Eng. 2017, 682, 527-534. [CrossRef]

3. Ravi, A.M.; Sietsma, J.; Santofimia, M.J. Exploring bainite formation kinetics distinguishing grain-boundary and autocatalytic nucleation in high and low-Si steels. Acta Mater. 2016, 105, 155-164. [CrossRef]

4. Kabirmohammadi, M.; Avishan, B.; Yazdani, S. Transformation kinetics and microstructural features in low-temperature bainite after ausforming process. Mater. Chem. Phys. 2016, 184, 306-317. [CrossRef]

5. Ravi, A.M.; Sietsma, J.; Santofimia, M.J. Bainite formation kinetics in steels and the dynamic nature of the autocatalytic nucleation process. Scr. Mater. 2017, 140, 82-86. [CrossRef]

6. Samanta, S.; Biswas, P.; Singh, S.B. Analysis of the kinetics of bainite formation below the MS temperature. Scr. Mater. 2017, 136, 132-135. [CrossRef]

7. Wu, H.D.; Miyamoto, G.; Yang, Z.G.; Zhang, C.; Chen, H.; Furuhara, T. Incomplete bainite transformation in Fe-Si-C alloys. Acta Mater. 2017, 133, 1-9. [CrossRef]

8. Soliman, M.; Palkowski, H. Development of the low temperature bainite. Arch. Civ. Mech. Eng. 2016, 16, 403-412. [CrossRef]

9. Varshney, A.; Sangal, S.; Kundu, S.; Mondal, K. Super strong and highly ductile low alloy multiphase steels consisting of bainite, ferrite and retained austenite. Mater. Des. 2016, 95, 75-88. [CrossRef]

10. Tsai, Y.T.; Lin, C.R.; Lee, W.S.; Huang, C.Y.; Yang, J.R. Mechanical behavior and microstructural evolution of nanostructured bainite under high-strain rate deformation by Hopkinson bar. Scr. Mater. 2016, 115, 46-51. [CrossRef]

11. Golchin, S.; Avishan, B.; Yazdani, S. Effect of $10 \%$ ausforming on impact toughness of nano bainite austempered at $300{ }^{\circ} \mathrm{C}$. Mater. Sci. Eng. A 2016, 656, 94-101. [CrossRef]

12. Asako, S.; Kawabata, T.; Aihara, S.; Kimura, S.; Kagehira, K. Micro-processes of brittle fracture initiation in bainite steel manufactured by ausforming. Procedia Struct. Integrity 2016, 2, 3668-3675. [CrossRef]

13. Yang, J.; Wang, T.S.; Zhang, B.; Zhang, F.C. Microstructure and mechanical properties of high-carbon Si-Al-rich steel by low-temperature austempering. Mater. Des. 2012, 35, 170-174. [CrossRef] 
14. Yoozbashi, M.N.; Yazdani, S.; Wang, T.S. Design of a new nanostructured, high-Si bainitic steel with lower cost production. Mater. Des. 2011, 32, 3248-3253. [CrossRef]

15. Khare, S.; Lee, K.; Bhadeshia, H.K.D.H. Carbide-Free Bainite: Compromise between Rate of Transformation and Properties. Met. Mater. Trans. A 2010, 41, 922-928. [CrossRef]

16. Soliman, M.; Mostafa, H.; El-Sabbagh, S.; Palkowski, H. Low temperature bainite in steel with 0.26 wt.\% C. Mater. Sci. Eng. A 2010, 527, 7706-7713. [CrossRef]

17. Gong, W.; Tomota, Y.; Koo, M.S.; Adachi, Y. Effect of ausforming on nanobainite steel. Scr. Mater. 2010, 63, 819-822. [CrossRef]

18. Bhadeshia, H.K.D.H. Nanostructured bainite. Proc. R. Soc. A Math. Phys. Eng. Sci. 2009, 466, 3-18. [CrossRef]

19. Garcia-Mateo, C.; Caballero, F.; Bhadeshia, H.K.D.H. Development of Hard Bainite. ISIJ Int. 2003, 43, 1238-1243. [CrossRef]

20. Caballero, F.G.; Bhadeshia, H.K.D.H. Very strong bainite. Curr. Opin. Solid State Mater. Sci. 2004, 8, 251-257. [CrossRef]

21. Ji, C.-X.; Cui, Y.; Zeng, Z.; Tian, Z.-H.; Zhao, C.-L.; Zhu, G.-S. Continuous casting of high-Al steel in shougang jingtang steel works. J. Iron Steel Res. Int. 2015, 22, 53-56. [CrossRef]

22. Cui, H.; Zhang, K.; Wang, Z.; Chen, B.; Liu, B.; Qing, J.; Li, Z. Formation of surface depression during continuous casting of high-Al TRIP steel. Metals 2019, 9, 204. [CrossRef]

23. Akram, M.; Palkowski, H.; Soliman, M. High-Strength Low-Cost Nano-Bainitic Steel. J. Mater. Eng. Perform. 2020, 29, $2418-2427$. [CrossRef]

24. Tian, J.-Y.; Xu, G.; Zhou, M.-X.; Hu, H.-J.; Xue, Z.-L. Effects of Al addition on bainite transformation and properties of high-strength carbide-free bainitic steels. J. Iron Steel Res. Int. 2019, 26, 846-855. [CrossRef]

25. Toji, Y.; Matsuda, H.; Raabe, D. Effect of Si on the acceleration of bainite transformation by pre-existing martensite. Acta Mater. 2016, 116, 250-262. [CrossRef]

26. Gong, W.; Tomota, Y.; Harjo, S.; Su, Y.H.; Aizawa, K. Effect of prior martensite on bainite transformation in nanobainite steel. Acta Materialia 2015, 85, 243-249. [CrossRef]

27. Huang, H.; Sherif, M.; Rivera-Díaz-Del-Castillo, P. Combinatorial optimization of carbide-free bainitic nanostructures. Acta Mater. 2013, 61, 1639-1647. [CrossRef]

28. Soliman, M.; Palkowski, H. Tensile properties and bake hardening response of dual phase steels with varied martensite volume fraction. Mater. Sci. Eng. A 2020, 777, 139044. [CrossRef]

29. Soliman, M.; Palkowski, H. Influence of hot working parameters on microstructure evolution, tensile behavior and strain aging potential of bainitic pipeline steel. Mater. Des. 2015, 88, 759-773. [CrossRef]

30. Cullity, B.D. Elements of X-ray Diffraction, 2nd ed.; Addison-Wesley, Reading, Mass.: London, UK, 1978.

31. Dyson, D.J. Effect of alloying additions on the lattice parameter of austenite. J. Iron Steel Inst. 1970, 208, 469-474.

32. Mateo, C.G.; Caballero, F.; Miller, M.K.; Jiménez, J.A. On measurement of carbon content in retained austenite in a nanostructured bainitic steel. J. Mater. Sci. 2011, 47, 1004-1010. [CrossRef]

33. Podder, A.S.; Bhadeshia, H. Thermal stability of austenite retained in bainitic steels. Mater. Sci. Eng. A 2010, 527, 2121-2128. [CrossRef]

34. Xu, Y.; Xu, G.; Mao, X.; Zhao, G.; Bao, S. Method to Evaluate the Kinetics of Bainite Transformation in Low-Temperature Nanobainitic Steel Using Thermal Dilatation Curve Analysis. Metals 2017, 7, 330. [CrossRef]

35. Garcia-Mateo, C.; Caballero, F.; Bhadeshia, H.K.D.H. Acceleration of Low-temperature Bainite. ISIJ Int. 2003, 43, 1821-1825. [CrossRef]

36. Garcia-Mateo, C.; Caballero, F. Ultra-high-strength Bainitic Steels. ISIJ Int. 2005, 45, 1736-1740. [CrossRef]

37. Singh, S.; Bhadeshia, H. Estimation of bainite plate-thickness in low-alloy steels. Mater. Sci. Eng. A 1998, 245, 72-79. [CrossRef]

38. Jacques, P.; Girault, E.; Mertens, A.; Verlinden, B.; Van Humbeeck, J.; Delannay, F. The Developments of Cold-rolled TRIP-assisted Multiphase Steels. Al-alloyed TRIP-assisted Multiphase Steels. ISIJ Int. 2001, 41, 1068-1074. [CrossRef]

39. Singh, K.; Kumar, A.; Singh, A. Effect of Prior Austenite Grain Size on the Morphology of Nano-Bainitic Steels. Met. Mater. Trans. A 2018, 49, 1348-1354. [CrossRef]

40. Yang, J.; Qiu, H.; Xu, P.; Yu, H.; Wang, Y. The substitution of aluminum for cobalt in nanostructured bainitic steels. AIP Conf. Proc. 2018, 1971, 20001. [CrossRef]

41. Guo, L.; Roelofs, H.; Lembke, M.I.; Bhadeshia, H.K.D.H. Modelling of size distribution of blocky retained austenite in Si-containing bainitic steels. Mater. Sci. Technol. 2018, 34, 54-62. [CrossRef]

42. Isasti, N.; Jorge-Badiola, D.; Taheri, M.L.; Uranga, P. Microstructural Features Controlling Mechanical Properties in Nb-Mo Microalloyed Steels. Part II: Impact Toughness. Met. Mater. Trans. A 2014, 45, 4972-4982. [CrossRef]

43. Gutiérrez, I. Effect of microstructure on the impact toughness of Nb-microalloyed steel: Generalisation of existing relations from ferrite-pearlite to high strength microstructures. Mater. Sci. Eng. A 2013, 571, 57-67. [CrossRef]

44. Kim, M.T.; Park, T.M.; Baik, K.H.; Choi, W.S.; Choi, P.P.; Han, J. Crucial microstructural feature to determine the impact toughness of intercritically annealed medium-Mn steel with triplex-phase microstructure. Acta Materialia 2019, 164, 122-134. [CrossRef]

45. Li, J.; Cheng, L.; Zhang, P.; Wang, L.; Li, H. Effect of delta ferrites on the anisotropy of impact toughness in martensitic heat-resistant steel. Mater. Res. Technol. 2019, 8, 1781-1788. [CrossRef]

46. Bhadeshia, H.; Edmonds, D. The mechanism of bainite formation in steels. Acta Met. 1980, 28, 1265-1273. [CrossRef] 